\title{
Bacterial cardiomyopathy: A review of clinical status and meta-analysis of diagnosis and clinical management
}

\author{
Aref Albakri* \\ Department of internal medicine, St-Marien hospital Bonn Venusberg, Bonn, Germany
}

\begin{abstract}
Primary bacterial infection of the myocardium without associated endocarditis is a rare cause of cardiomyopathy (BCM). Staphylococcus aureus is the most common aetiological agent of BCM although infections with a broad range of other bacterial pathogens may also cause the disease. BCM is a major long-term sequela of myocarditis, which usually develops in the setting of overwhelming bacteraemia and sepsis. It has a wide spectrum of clinical manifestations ranging from a subclinical self-limiting flu-like illness to life-threatening arrhythmias, heart failure and even death. Its typical pathophysiological features include multifocal studding of the myocardium with tiny abscesses and the involvement of the left ventricle. The disease may lead to cardiac dysfunction, rhythm disturbances and myocardial rapture with or without secondary purulent pericarditis. Due to a very low incidence in modern clinical practice, there are no large-scale clinical trials on BCM. Almost all information about BCM originates from autopsy studies performed during the pre-antibiotic era with a few recent case reports and observational studies. The lack of clinical trials has undermined a specific understanding of BCM. This paper reviews published literature on aetiology, pathophysiology, diagnosis and clinical management of BCM as well as highlights implications for clinical practice and future research.
\end{abstract}

\section{Introduction}

Myocarditis (MC) is a potentially life-threatening inflammatory disease of the myocardium and one of the most important causes of dilated cardiomyopathy (DCM). Most often, MC results from viral infection, and less commonly, specific forms of MC may result from bacterial and protozoal infections, toxins, drug reactions and autoimmune diseases [1]. Bacterial infection is a rare cause of MC and DCM because the widespread use of antibiotics and vaccinations have significantly suppressed the persistence of bacterial infection. The majority of published cases of bacterial MC or cardiomyopathy (CM) are autopsy studies that predate the use of antibiotics [2]. As a result, most of the current evidence on the pathophysiology, diagnosis and clinical management strategies of infectious aetiologies of MC or CM rely almost entirely on studies on viral infections, which may not entirely apply to bacterial causes of CM. However, continued publications of case reports and observational studies on bacterial cardiomyopathy $(\mathrm{BCM})$ in recent years has created the present need to evaluate published evidence on the pathophysiology, diagnosis and treatment of bacterial $\mathrm{MC}$ and $\mathrm{CM}$. The aim is to improve the understanding of the clinical status of this rare but potentially fatal form of infective cardiomyopathy as well to identify areas that would benefit from additional research.

\section{Definitions}

The American Heart Association (AHA) and the European Society of Cardiology (ESC) define cardiomyopathy as a progressive myocardial disorder characterized by mechanical and/or electrical dysfunction that usually manifests with ventricular hypertrophy or dilatation in the absence of coronary artery disease, hypertension, valvular disease and congenital heart disease in sufficient quantities to cause the observed myocardial abnormality $[3,4]$. DM, which is a form of CM as well as a major long-term sequela of MC due to bacterial infections among other pathogens, has been defined as a progressive myocardial disorder marked by left ventricular (LV) or biventricular dilation and contractile dysfunction not explained by chronic abnormal loading conditions or coronary artery disease [4]. Based on the foregoing definitions, and from an aetiological standpoint, BCM may be defined as a subtype of DCM resulting from persistent bacterial infection in a dilated myocardium in the absence of any other known cause marked by conduction abnormalities accompanied by structural and/or functional cardiac abnormalities.

\section{Aetiologic agents}

Primary bacterial infection as the cause of infective MC and its sequela DCM is rare, with an incidence rate of $0.2 \%$ to $1.5 \%$ [5]. It is rare because myocardial tissues are usually intact and generally unfertile for bacterial infections, which limits both the frequency and the persistence of infection [6]. The 2013 ESC Position Statement on Myocarditis lists the most common bacterial pathogens (bacteria, rickettsia and spirochaetal) whose infection of the myocardium may result in the development of bacterial MC and/or CM (Table 1).

\section{Bacteria}

Staphylococcus: Staphylococcus is a facultative anaerobic grampositive sphere-shaped (coccal) bacterium. It is a usual member of the microbiota of the human body commonly occurring on the skin or in the upper respiratory tract. Typical transmission pathways are direct contact with infected nasal discharges, contact with fomites (contaminated objects) or inhalation of bacteria-laden aerosols [8]. In most cases, they cause no health problems. In fewer cases, direct infection or production

${ }^{\star}$ Correspondence to: Aref Albakri, Department of internal medicine, St-Marien hospital Bonn Venusberg, Bonn, Germany, E-mail: arefalbakri@yahoo.com

Key words: bacterial cardiomyopathy, bacterial myocarditis

Received: April 02, 2019; Accepted: April 26, 2019; Published: April 29, 2019 
Table 1. Cardiomyopathy-associated bacterial pathogens and their primary diseases

\begin{tabular}{|c|c|c|}
\hline Bacteria & Type of Bacteria & Disease(s) Caused \\
\hline \multirow{10}{*}{ Bacteria } & Staphylococcus & $\begin{array}{l}\text { Mild skin infections (pimples, impetigo, boils, cellulitis, folliculitis, } \\
\text { carbuncles, scalded skin syndrome or abscesses) }\end{array}$ \\
\hline & Streptococcus & Rheumatic fever, pharyngitis, scarlet fever or infant meningitis \\
\hline & Salmonella & Typhoid fever, scarlet fever, septicaemia gastroenteritis \\
\hline & Corynebacterium Diphtheriae & Diphtheria \\
\hline & Meningococcus & Meningococcemia and meningitis \\
\hline & Gonococcus & Gonorrhoea \\
\hline & Haemophilus influenzae & Meningitis, epiglottitis, cellulitis \\
\hline & Mycoplasma pneumoniae & Bronchopneumonia. \\
\hline & Brucella & Brucellosis \\
\hline & Mycobacterium & Tuberculosis \\
\hline \multirow{3}{*}{ Rickettsial } & Coxiella burnetii & Q Fever \\
\hline & R. rickettsii & Rocky Mountain spotted fever \\
\hline & R. tsutsugamuschi & Scrub typhus \\
\hline \multirow{3}{*}{ Spirochaetal } & Borrelia & Lyme disease \\
\hline & Leptospira & Weil Disease \\
\hline & Treponema & Syphilis \\
\hline
\end{tabular}

of toxin by the bacteria may lead to a variety of illnesses ranging from relatively minor skin diseases such as pimples, impetigo, boils, cellulitis, folliculitis, carbuncles, scalded skin syndrome and abscesses to potentially life-threatening diseases such as pneumonia, meningitis, osteomyelitis, endocarditis, toxic shock syndrome, bacteraemia and sepsis. Staphylococcus aureus (S. aureus) is a member of staphylococcal bacteria and one of the most recognized cause of bacterial MC [6,7]. The exact epidemiology of $S$. aureus associated MC is unknown because of the infrequent use of endomyocardial biopsy (EMB: the diagnostic gold standard) despite the lack of an alternative reliable and widely available non-invasive diagnostic standard [9]. Earlier studies reported S. aureus is a common cause of bacterial MC without associated endocarditis. In an analysis of cases of staphylococcal myocardial abscesses, Flaxman [10] reported 17 out of 23 cases while Samson [11] reported 9 out of 14 cases without associated endocarditis. Case reports associate $S$. aureus with septic shock due to staphylococcal bacteraemia, death due to ventricular rupture [12], and risk factors such as end-stage renal disease on haemodialysis [13], steroid-dependent Crohn's disease and initiation of Infliximab [14], and the presence of AIDs [15]. A recent case report found an isolated case of $S$. aureus MC with no evidence of valvular involvement and LV apical thrombi in patients with normal LV systolic function [9].

Streptococcus: Streptococcus is a gram-positive, non-motile, nonspore-forming, catalase-negative spherical bacterium occurring in pairs or chains. Most members are facultative anaerobes while fewer are obligate anaerobes. They are part of the endogenous microbial flora of the nasopharynx and skin, and spread by respiratory secretions and fomites [16]. In humans, two species - $S$ pyogenes (Group A streptococci) and $S$ pneumoniae (pneumococci) may cause severe diseases. Acute streptococcus infection may cause pharyngitis, scarlet fever, impetigo, cellulitis or erysipelas while invasive infections may cause necrotizing fasciitis, myositis and streptococcal toxic shock syndrome [17]. Some patients may develop immune-mediated sequela such as acute rheumatic fever, glomerulonephritis, endocarditis and MC [17]. Although myocardial involvement is rare, Streptococcus may infect the myocardium through immune-mediated reaction manifesting as rheumatic fever or through direct invasion of the myocardium [6]. Infection occurs after 2 to 3 week-period of latency. In some instances, MC occurs within a few days post infection, which does not fit the criterion for rheumatic fever [18,19]. Myocarditis associated with streptococcal infection mimics myocardial infarction with typical chest pains, ECG changes and troponin elevation [18]. Viridans streptococci have been included in the list of bacterial aetiologies of myocardial abscess in some series, but it remains unclear whether the process can occur in the absence of bacterial endocarditis [20]. Streptococcus pneumoniae is another recognized aetiology of bacterial MC, which manifests in the setting of pneumococcal bacteraemia with reports of fatal rapture of pneumococcal abscess into the pericardium [6].

Meningococcus: Meningococcus, also referred to as Neisseria meningitis, is a gram-negative bacterium and the leading cause of fatal sepsis (meningococcemia) and sporadic cases of meningitis [21,22]. The bacterium usually colonizes the naso-oropharyngeal mucosa. To cause invasive disease, the bacteria attach and invade respiratory epithelium, enter the circulation system and multiply by evading bacterial activity [23]. Myocardia involvement following meningococcal infection has been described in a high proportion of fatal cases of meningococcemia [24,27]. The focal nature of neutrophilic inflammatory infiltrate in the myocardium resembles that observed in patients with systemic infections accompanied by myocardial inflammation due to $R$. rickettsia infection [23]. Myocardial inflammatory infiltrates based on immunohistochemical evidence of meningococci and meningococcal antigens suggest the inflammation is a direct result of meningococcal infection of the myocardium [27]. Earlier case reports have described two fatal cases of meningococci MC with autopsy revealing intense polymorphonuclear cell infiltrate with gram-negative diplococci in the myocardium and involvement of the HIS bundle, a case of myopericarditis in a patient with meningococci meningitis and bacteraemia [28-30].

Salmonella: Salmonella species are gram-negative, flagellated, facultative anaerobic bacilli responsible for significant morbidity and mortality in both developing and developed nations. The major transmission pathway is contaminated food since Salmonella is a zoonosis with enormous animal reservoir including chicken, turkeys, pigs and cows [31]. Since Salmonella survive in meat and animal products not thoroughly cooked, animal products are the main vehicle of transmission. Person-to-person spread of salmonellae also occurs but very rarely. When ingested, Salmonella survive gastric acid and invade the mucosa of the small and large intestines. Invasion of epithelial cells induced inflammatory reaction causing ulceration and destruction of the mucosa leading to gastroenteritis, septicaemia and enteric (typhoid) fevers as well as a range of clinical syndromes 
including diarrhoea disorders (non-typhoid Salmonella [NTS]) [31]. The bacteria can also disseminate from the intestines to cause systemic disease. Salmonella infection with myocardial involvement as a part of extra-intestinal manifestation is rare. There is only about $5 \%$ incidence of Salmonella invasion beyond the gastro-intestinal tract, mostly observed in immunocompromised patients [32]. Most case reports describe myocarditis associated with S. Typhi and S. Paratyphi infections. Myocarditis associated with NTS, which is common in the western hemisphere, has had fewer reports [32]. Although there is no structured analysis on myocarditis associated with salmonella, common signs may include ST segment elevation and elevated troponin levels [33].

Haemophilus influenzae: Haemophilus Influenzae is a gramnegative coccobacillary anaerobic pathogenic bacterium similar in ultrastructural features to other pathogenic bacilli. They colonize the nasopharynx, and may penetrate the epithelium and capillary endothelium to cause infective and systemic diseases. Type B $H$. influenzae may cause meningitis, epiglottitis, bacteraemia, and cellulitis while nontypeable $H$. influenzae may cause otitis media, sinusitis, tracheobronchitis and pneumonia [34]. Myocardial involvement associated with pandemic influenzae is more common in hospitalized patients compared to seasonal influenza virus outbreaks [35]. In Japan, $H$. Influenzae is an important aetiologic agent of fulminant myocarditis although in other regions reports of fulminant myocarditis is exceedingly rare [35]. Myocardial infection may reverse after antimicrobial treatment but in some cases, depending perhaps by region, the disease may worsen. For instance, during the $2009 \mathrm{H}$. Influenzae pandemic in Japan, all patients recovered without any sequelae, while in Canada, critical illness occurred rapidly after hospitalization [36,37].

Corynebacterium diphtheriae: Corynebacterium diphtheriae is a non-motile, non-capsulated, club-shaped, gram-positive bacillus. The bacterium commonly occurs in the nasopharynx or the skin, and its spread solely among humans by droplets, secretions or direct contact, although toxigenic strains have been isolated from horses. Infection by $C$. diphtheriae is the aetiological agent of two clinical forms of diphtheria - nasopharyngeal and cutaneous diphtheria [34]. In areas where diphtheria is endemic, asymptomatic nasopharyngeal carriage is common but in susceptible individuals, toxigenic strains may cause diseases by multiplication and secretion of diphtheria toxin in the nasopharyngeal or skin lesions. Diphtheria is rare in Western countries but still an important cause of morbidity and mortality in developing countries possibly due to improved vaccination programs. Although cardiac involvement is rare, $C$. diphtheriae infection associated with myocarditis is the most common cause of death in diphtheria patients through the action of exotoxin produced by the bacterium [34].

Mycoplasma Pneumoniae: Mycoplasma pneumoniae are members of mycoplasma, which are the smallest and simplest self-replicating bacteria. They are spherical to filamentous organisms with no cell walls and thus placed in a separate class Mollicutes. They are surface parasites colonizing the human respiratory and urogenital tracts and usually spread by close personal contact. Infection by mycoplasma pneumoniae in humans include subclinical infection, upper respiratory disease and bronchopneumonia [38]. However, in a majority of cases, infection does not progress to clinically evidence pneumonia, and if it does, the onset is usually gradual and the clinical picture is mild to moderate severe illness with a long (4 to 6 weeks) convalescence. $M$. pneumoniae infection is usually accompanied by mild myocarditis with up to $33 \%$ of cases showing ECG abnormalities [38]. M. pneumoniae associated respiratory tract infections may be accompanied by cardiac complications in up to $5 \%$ of the cases [39]. Myocardial involvement is rare and patients present solely with respiratory symptoms, which may not encourage the need for tests to identify cardiomegaly, ECG abnormalities and serological testing as part of the routine work-up in suspected patients [39].

Gonococcus : Gonococcus, also known as Neisseria gonorrhoea, is a member of the family Neisseriaceae and genus Neisseria. It is a gram-negative diplococcus obligate bacterium with a high tropism for superficial human mucosal surfaces. Gonococcus colonize superficial mucosal surface lined with columnar epithelium mostly involving cervix, urethra, rectum, pharynx, and conjunctiva. The main transmission pathway is sexual contact and usually affect the mucosal membranes of the urethra in men and the end cervix in women, and in some cases, the infection may disseminate to a variety of tissues [40]. Gonococcus is the aetiologic agent for gonorrhoea, with a high prevalence but low mortality. Although gonococcal infects the urethra, cervix, and pharynx, in about $0.5 \%$ to $3.0 \%$ of cases, the bacterium disseminates into the blood stream to affect other body organs including the heart. However, even with dissemination, cardiac involvement associated with gonorrhoea is rare [40].

Brucella: Brucella are gram-negative non-spore forming and nonmotile, aerobic coccobacilli. In humans, three species ( $B$ melitensis, $B$, arbortus and $B$ suis) are important pathogens. Brucella is a zoonosis transmitted from handling infected animals or consuming contaminated milk or milk products. Brucella enter the humans system through the mouth, conjunctival, respiratory tract and abraded skin, and spread in reticuloendothelial sites to cause brucellosis [41]. Control of the disease is mainly through pasteurization of milk and milk products, vaccination or the destruction of infected animals. Usually, most infected individuals recover within 3 to 12 months but a few may develop complications involving various organs including the heart. However, cardiac complications of Brucella infection are rare (approximately 1.5\%). In particular, myocarditis, in the absence of concomitant endocarditis, is very rare. However, Brucella infection should be considered as a possible aetiologic agent of myocarditis in endemic areas [41].

Mycobacterium: Mycobacterium is slender, curved rods that is acid-fast and resistant to acids, alkalis, and dehydration. They are members of Mycobacterium tuberculosis complex (M tuberculosis, $M$. bovis, M. africanum and M. microtii) and nontuberculous species. Infections occurs by airborne transmission of droplet nuclei contaminated with a few viable virulent bacteria produced by sputum positive individual. The bacilli colonize the alveolar spaces for the lungs and eliminated by the alveolar macrophages but a few may persist, multiply and kill the macrophages [42]. Mycobacterium are etiological agents for tuberculosis, which affects the lower respiratory system and characterized by chronic productive cough, mild fever, night sweat and weight loss. Usually, in mycobacterium infection (tuberculosis), myocardial involvement is very rare but there are reports that it can present with sudden cardiac (even in the absence of disseminated mycobacterium), atrioventricular block, ventricular arrhythmias or congestive heart failure. Nevertheless, diagnosis of mycobacterium should be considered in at risk individuals presenting with fulminant myocarditis [42].

\section{Rickettsia}

Rickettsia are obligate intracellular small gram-negative pathogens. Their transmission is via arthropod vectors including mites, ticks, flies, fleas and lice. Symptomatic cardiac involvement in rickettsial infection 
is uncommon. Myocarditis associated with R. rickettsia (aetiologic agent of Rocky Mountain spotted fever [RMSF]), R. tsutsugamuschi, (aetiologic agent of Scrub Typhus) and Coxiella burnetii (aetiologic agent of $\mathrm{Q}$ fever) have been reported [43]. Cardiac involvement may be more prevalent than reported because of a wide variability in severity and the lack of specificity of clinical presentation. Since the $R$. rickettsia has a special tropism for endothelial cells, myocarditis usually results from disseminated endothelial infection of small blood vessels or by secondary immune-mediated mononuclear inflammatory reaction [43].

R. rickettsia: $R$. rickettsia is a non-motile, gram-negative, nonspore forming, highly pleomorphic bacteria. Its infection often involves myocardial tissue as part of widespread vasculitis of the venuoles, capillaries and arterioles, particularly in fatal cases [44-47]. RMSF has high mortality rates ( $4 \%$ to $8 \%$ ) possibly reflecting delayed diagnosis [48]. Walker et al. performed a blinded review of nine cases of fatal RMSF and nine age-matched controls and found all RMFS cases had lymphocytic infiltrates between myofibrils greater than those observed in controls [46]. Heart weights were increased but with no evidence of ventricular failure or dilatation. Immunofluorescent staining of myocardial tissue for $R$. rickettsia was positive in eight cases. The single negative case had been treated with antimicrobial (chloramphenicol) for five days. The location of $R$. rickettsia was between myocardial fibres consistent with infection of the vascular endothelium of small blood vessels. None was observed inside the myocardial fibres and little or no necrosis of myocardial fibres was observed suggesting cardiac involvement in $R$. rickettsia infection but with insignificant contribution to mortality. Myocarditis in RMSF may go unrecognized since diagnosis by immunofluorescence antibody titter to rickettsial antigens $\geq 1: 64$ is not achieved until second week of illness [49].

C. burnetti: C. burnetii is an obligate intracellular pathogen and the aetiologic agent for $\mathrm{Q}$ fever. The organism proliferates in the phagolysosome of the host cell. Humans acquire the disease through inhalation of the organisms aerosolized from infected animals or infected tissues such as the placenta [50]. Cardiac disease usually manifests as endocarditis but cases of acute Q fever-induced myocarditis have been described [51]. Myocarditis complicating Q fever can occur at any age with a more severe manifestation compared to other cases of Q fever. In a French series of 1276 cases with the acute form of $C$. burnetti infection, two of the 12 deaths were due to cardiac complications of myocarditis. Acute Q fever myocarditis shows ECG abnormalities particularly $\mathrm{T}$-wave changes and positive serologic tests for chronic phase of the disease for C. burnetti antibodies (a single titre of $\operatorname{IgM} \geq 1: 50$ and/or $\operatorname{IgG} \geq 1: 200$, or by a series of titres that become increasingly positive) [52]. Cross-reacting antibodies may be responsible for autoimmune-mediated myocardial damage [50]. Direct damage to myocardial cells may occur supported by evidence from $\mathrm{C}$. burnetti culture from tissues obtained from EMB [51].

R. tsutsugamuschi: $R$. tsutsugamuschi (Orientia tsutsugamuschi) is the aetiologic agent for scrub typhus, whose infection usually manifests as febrile illness, headache, maculopapular rash and multiorgan involvement including pneumonia, meningoencephalitis and myocarditis. Scrub typhus is prevalent in Asian Pacific region and infection is usually via chigger (berry bug) bite causing the formation of an eschar [53]. At present, data for the incidence of myocarditis associated with scrub typhus is unavailable. In post-mortem analysis of 31 U.S. soldiers during World War II who died due to scrub typhus, $81 \%$ exhibited varying degrees of myocardial inflammation but the effect on cardiac function or death was not evaluated [54]. Although MC associated with infection by $R$. tsutsugamuschi may occur frequently, it is mostly transient with no residual cardiac dysfunction and thus may not be easily recognized. Permanent cardiac damage is unlikely based on clinical outcomes and histologic observations [55,56]. However, deaths associated with ventricular arrhythmias have been reported [56]. The onset of symptoms of myocarditis may delay for several weeks after diagnosis of acute scrub typhus because of incomplete treatment or persistence of residual organisms in the cardiac endothelial tissues [55]. R. tsutsugamuschi infects endothelial cells and may lead to cell apoptosis and focal and disseminated vasculitis and perivasculitis involving small blood vessels. On-specific myocyte injury with minimal necrosis can occur because of injury to the endothelial cells and inflammatory response by infiltrating lymphocytes, monocytes, plasma cells associated with haemorrhage and oedema resulting from adjacent infection [57]. The lack of significant myofibril necrosis may explain the absence of chronic cardiac sequelae [56].

Spirochaetal: Spirochaetal are a type of slender, elongated, spirally twisted along the axis, and highly motile gram-negative bacteria. Three genera of spirochaetal can cause human infection: (a) Treponema causes syphilis and the non-venereal treponematoses; (b) Borrelia causes Lyme disease and relapsing fever; and (c) Leptospira causes leptospirosis or Weil disease. Only Lyme disease and Weil disease have been associated with myocardial involvement and myocarditis $[58,60]$.

Borrelia: Lyme disease due to Borrelia infection is transmitted to humans by hard-bodied ticks found in temperate climates [61]. The hallmark of Lyme disease is erythema migrants (an expanding red rash), which occurs in approximately $90 \%$ of diagnosed cases [62]. Other clinical manifestation become apparent after the bacteria disseminate from the site of initial infection in the skin to the heart and other organs. The prevalence of the disease has decreased significantly after the advent and the use of antibiotic therapy in the course of infection [58]. Myocardial involvement occurs when Borrelia (Lyme bacteria) disseminate from site of infection to establish infection in cardiac tissue. Myocarditis associated with Lyme disease may be accompanied by joint or nervous system manifestations but the heart remains the only site of clinically apparent disease $[63,64]$. Early studies reported myocarditis with or without pericardial involvement occurred in approximately $4 \%$ to $10 \%$ of untreated Lyme disease and the rate goes significantly higher with the inclusion of asymptomatic carditis [63]. Lyme bacteria damage myocardial tissues via inflammation that occurs when the host immune cells respond to bacterial infection. Typical cardiac manifestation is partial heart block due to impaired electrical signal that controls contraction of the upper and lower cardiac chambers. The heart block is mild and transient, resolving within six weeks after onset. Typical symptoms include light-headedness, fainting, shortness of breath, palpitations and/or chest pains with very few cases of reported deaths [58].

Leptospira: First described in 1886, Weil disease is a severe form of leptospirosis, which is a ubiquitous zoonosis transmitted to humans via water contaminated with animal urine or faeces. Recently, the death of a British Olympic rower from Weil disease has raised awareness among the public and medical profession about this uncommon but potentially deadly disease $[62,65]$. Transmission of the bacteria from contaminated water occurs through broken skin, mucus membranes and conjunctivae, with farmers and people living in urban slums at the highest risk [66]. However, diagnosis should be considered in all individuals likely to have had contact with potentially infected animals, soil or surface waters contaminated with animal urine, or those working in sewers or participating in certain water sports like canoeing [67-69]. 
Myocarditis is an underestimated complication of Weil disease because it is frequently asymptomatic. Common symptoms of myocarditis associated with Weil's disease include arrhythmias, conductivity impairment and non-specific terminal phase abnormalities usually with non-specific ECG changes [61].

Treponema: Treponema are helically coiled, corkscrew-shaped bacteria. Humans are the only natural host (there is no-known nonhuman reservoir). Infection by treponema occurs through sexual contact, blood transfusion from individuals with incubating syphilis or vertically from infected mother to her newborn child [70]. Upon infection, treponema penetrates the mucosal membranes or enter minuscule breaks in the skin. Treponema pallidum is the aetiologic agent for venereal syphilis, which if left untreated, becomes a chronic disease characterized with asymptomatic intervals. In individuals with acquired venereal syphilis, the disease develops through three stages: initial genital tract lesion (primary stage); disseminated lesions (secondary stage); and approximately a third of untreated individuals show cardiovascular and neuroglia complications (tertiary stage) [71]. If left untreated, cardiac involvement in syphilis (cardiovascular syphilis) is common during the tertiary stage of the disease (persistence treponema infection). Myocardial involvement may begin with transient myocardial inflammation with little or no impaired circulation. Later stages are characterized by syphilitic involvement of the heart confined almost purely to the aorta and aortic valve with the potential to develop into aortic insufficiency, dilation, cardiomegaly and ultimately HF [70,71].

\section{Pathophysiology}

\section{Pathophysiologic groups}

The exact pathophysiological mechanisms through which bacterial infections may lead to MC and its chronic sequela CM is incompletely understood. This is partly attributed a significant reduction in incidences of bacterial MC or $\mathrm{CM}$ and the consequent the lack of recent studies specific to bacterial MC or CM. Studies done during pre-antibiotic era suggest several distinct pathophysiological patterns of BCM. In particular, Tenants and Parks described three group of BCM patients [72]. The first and the most commonly encountered in clinical practice are those with myocardial abscesses in the setting of overwhelming sepsis and usually the presence of other organs with abscesses in the absence of endocarditis. A classic review 240 cases of myocarditis associate the presence of pyemia with myocardial abscesses [73]. The second group included patients with endocarditis who developed myocardial abscess by direct extension. The third group included patients with abscesses only in the myocardium and absent in other organs. In a review of bacterial myocarditis, Wasi and Shuter described a fourth group of patients characterized by diffuse bacterial infiltration throughout the myocardium without discrete abscess formation [6].

\section{Pathophysiologic features}

The literature on the pathophysiology of BCM is scant. Most of what is currently known comes from autopsy series published during the pre-antibiotic era, which give a gross description of the myocardium without a clear description of the underlying mechanism and clinical course [73-76]. The presence of abscess in the myocardium emerges as a characteristic pathological feature in BCM. Flaxman analysed 14,160 autopsies performed between 1929 and 1942 out of which 29 cases showed evidence of myocardial abscess [74]. The 29 cases occurred across all age groups, with a greater proportion $(n=13 ; 45 \%)$ in children $(<18$ years), followed by infants $(n=5 ; 17 \%)$ and finally older patients $(>50$ years) $(n=3 ; 10 \%)$. The presence of myocardial abscess in the absence of endocarditis was common in almost three quarters of the reported cases (72\%), all of whom had remote foci of infection especially osteomyelitis and cellulitis.

Sanson et al. analysed 2,897 autopsies between 1940 and 1961, and described 23 cases of myocardial abscess, with an incidence of $1.5 \%$ of all autopsy cases [75]. The population was much older than that of Flaxman, fewer cases younger than 18 years $(n=1 ; 4 \%)$ with a majority older than 50 years $(n=13 ; 57 \%)$ [74]. In $74 \%$ of the cases, myocarditis abscess developed in the absence of endocarditis with most patients with proven bacteraemia and a recent history of surgery and/ or malignant disease. Disseminated abscesses (in kidneys, lungs, brain, liver, and adrenal glands) was common in $91 \%$ of the cases with the remaining $9 \%$ had myocardial abscess alone. Myocardial abscesses were multiple and minute with the involvement of the left ventricle (LV) in all the cases. The most common bacterial aetiological agent was Staphylococcus aureus.

In an analysis of autopsy series of 3,048 patients between 1967 and 1977, Abela et al. described 14 cases of myocardial abscesses in the absence of infective endocarditis [76]. Twelve cases were bacterial and two were protozoal. Disseminated abscesses were observed in $64 \%$ of the cases while $36 \%$ had only abscesses in the myocardium (only the heart was involved). The most common extra cardiac sites of abscesses were lungs, adrenal glands, thyroid glands and parietal pericardium. In conclusion, the authors observed that routine autopsy procedure of examining a single randomly selected section of the myocardium is inadequate, which may underestimates its true prevalence. Saphir described 32 cases of myocardial abscesses among 240 autopsy cases of $\mathrm{MC}$, all of which occurred in the presence of pyemia [73].

Kim et al. described 63 cases of myocardial abscesses from 12,359 autopsies between 1962 and 1975 translating to an incidence of $0.5 \%$ [77]. All the 63 cases exhibited multi-focal myocardial abscesses with $80 \%$ of the cases without co-existing infective endocarditis. Staphylococcus aureus was the most common bacterial pathogen responsible for the abscesses cultured from antemoterm blood of 22 patients. A majority of the 63 patients $(n=51 ; 63 \%)$ had disseminated abscesses in one or more extra-cardiac organs. Most of the myocardial abscesses appeared to result from disseminated sepsis although surgical conditions, malignancy and alcoholic hepatic disease were the most frequent primary conditions in cases with myocardial abscesses.

Besides abscesses, other less common presentations of bacterial $\mathrm{MC}$ or $\mathrm{CM}$ include infarcted tissues, abscess association with myocardial rapture and diffuse myocardial infiltration by bacteria [6]. Bacteria abscesses have been observed in both old infarcts and in acutely infarcted myocardium [78-81]. Pathophysiologic sequence of events leading to infarcted tissue is not established, but the belief of most authors is that it is the result of bacterial seeding of the normal myocardium. However, the bacteria may not be the cause of infarct or infection in most cases because mostly the infarcts are old, involved vessels often demonstrate severe atherosclerosis and the absence of septic emboli within coronary arteries. Abscess-associated rapture of the myocardium is rare in BCM patients although it has been described in each of the pathophysiologic groups and may be more common in abscesses involving infarcted tissues [72]. The last distinct presentation of $\mathrm{BCM}$ is diffuse bacterial $\mathrm{MC}$ in the absence of discrete abscess formation. This exceedingly rare pathological type of BCM has been observed in patients with meningococcal and Group B streptococcal myocarditis $[[73,82]$. 
Based on the autopsy evidence and proposed pathogenic mechanisms of the general bacterial myositis, myocardial abscess is a pathophysiological hallmark of BCM, which may be disseminated to other body organs with or without infective endocarditis usually in the setting of bacteraemia and sepsis [5,73-77]. The pathophysiology process of BCM may involve three phases. In the initial phase, bacterial invade the myocardium but a definitive purulent collection has not yet developed. This sub-acute phase occurs over 1 to 3 weeks [5]. The second phase involves the supportive stage (formation of abscesses) occurring 10 to 20 days. This is the phase where detection of myocarditis is usually established. Imaging should confirm abscess and aspiration would yield pus during this phase. If the infection remains undiagnosed and untreated, systemic findings including sepsis will develop as part of the third phase. Dissemination of abscess to other organs may also occur [5].

\section{Clinical presentation and investigation}

\section{Presentation}

Most studies on clinical presentation of infective MC focus on viral MC with very few data on bacterial MC and/or DCM. Although the heterogeneity of infective bacterial pathogens may present with a wide spectrum of clinical signs and symptoms, clinical presentation is dominated by symptoms and signs of overwhelming infection or cardiac involvement [6]. Most BCM patients present with febrile illness with some elements of sepsis syndrome. Symptoms of cardiac dysfunction may include angina, dyspnoea and orthopnoea. Physical signs may include tachycardia, hypotension, distended neck veins, gallop rhythms and pulmonary rales $[78,80,81]$. Paradoxical pulse and pericardial rub may be present in cases of myocardial rapture [29].

\section{Investigation}

Laboratory: Different clinical investigation tools are known to detect infective pathogens responsible for infective MC. Non-viral aetiologies, including bacterial pathogens, are often morphologically distinctive and thus identifiable by direct microscopic examination with routine and special stains - Gram's, Gomori's, periodic acid-Schiff and ZiehlNeelsen [34]. These microbiological cultures and other laboratory tests are useful for definitive diagnosis of causative infective bacterial pathogens. Usually, routine laboratory tests may detect leucocytosis with band forms indicating ongoing bacterial infection. The real world data of the Marburg Myocarditis Registry (MMR) containing 1,098 records of biopsied patients with suspected inflammatory DCM and/ or MC reveals common diagnosis methods of bacterial myocardial infection include serodiagnosis, blood culture and microscopy of sputum or pericardial fluid (Table 2). In some bacterial pathogens, serology alone may be insufficient for a confirmatory diagnosis and endomyocardial biopsy may be required to confirm diagnosis [82]. Chest roentgenogram (X-ray) may reveal cardiomegaly and pulmonary oedema $[80,81,83]$. Blood culture is generally positive and biochemical markers of cardiac injury may be elevated. Cardiac biomarkers such as troponins or creatine kinase lack specificity but may be useful to confirm diagnosis of MC $[84,85]$. In patients with acute MC, serum concentration of troponin I and $\mathrm{T}$ are elevated more frequently than creatine kinase myocardial band fraction, and higher concentrations of T may have a prognostic value. Non-specific markers of myocardial inflammation such as leukocytes may be elevated in acute MCs but lower values do not exclude acute myocardial inflammation [86,87].

Electrocardiogram: In acute infective MC, the electrocardiogram (ECG) may reveal sinus tachycardia with non-specific ST-segment and
T-wave abnormalities, which may be a consequence of direct cardiac injury or alterations in the host's physiologic and metabolic state such as hyperpyrexia, electrolyte abnormalities and perturbations of the respiratory and central nervous system (CNS) [11]. Occasionally, ECG changes may suggest acute myocardial infarction and may include STsegment elevation, ST-segment depression and pathologic Q-waves $[78,79]$. Pericarditis may infrequently accompany MC, and in these patients, pericardial involvement may present with pericarditis-like changes on the ECG [29]. Arrhythmias and conduction abnormalities suggesting bacterial invasion of the conduction system have also been described $[73,80]$. The sensitivity of the ECG for MC is low (47\%) [88]. In $\mathrm{MC}$ patients, the presence of $\mathrm{Q}$ waves ( $\mathrm{Q}$ duration $\geq 120 \mathrm{~ms}$ ) or left bundle-branch block has been associated with higher rates of death and heart transplantation [89,90].

Echocardiography: There are no specific echocardiographic features of infective MC because patterns consistent with dilated, hypertrophic and ischemic cardiomyopathies have been described in patients with histologically proven MC [1]. However, echocardiography allows the evaluation of cardiac chamber size, wall thickness, systolic and diastolic functions, and the presence of intracavity thrombi. In infective MC, its most prominent role is to rule out other causes of myocardial dysfunction or HF such as valvular heart disease or hypertrophic or restrictive cardiomyopathies [2]. Evaluation of different echocardiographic parameters is of prognostic relevance. For instance, fulminant MC patients usually exhibit normal cardiac chamber sizes with increased septal thickness due to acute myocardial oedema while acute MC patients have marked LV dilatations and normal wall thickness [91]. Mostly, echocardiographic tests have been used in the setting of viral MC and DCM but reports for their use for myocardial abscesses is unknown.

Magnetic Resonance Imaging: The utility of cardiac magnetic resonance imaging (MRI) for the assessment of patients with suspected MC and/or DCM has been increasing [92-98]. With a unique potential for tissue characterization particularly with the use of T1- and T2weighted images cardiac MRI can assess three markers for cardiac injury - (a) intracellular and interstitial oedema; (b) hyperaemia and capillary leakage; and (c) necrosis and fibrosis $[96,99]$. A white paper by the International Consensus Group on Cardiovascular Magnetic Resonance in Myocarditis recommends the performance of cardiac MRI in symptomatic patients with clinical suspicion of MC in whom MRI findings will affect clinical management [99]. The white paper proposes cardiac MRI criteria for the diagnosis of MC based on the Lake Louise Criteria have been proposed].

A. Cardiac MRI is consistent with myocardial inflammation if at least 2 of the following criteria are present:

a) Regional or global myocardial signal intensity increase in T2weighted images;

b) Increased myocardial global early enhancement ratio between myocardium and skeletal muscle in gadolinium enhanced T1weighted images;

c) At least one focal lesion with non-ischemic regional distribution in inversion recovery-prepared gadolinium enhanced T1weighted images.

B. Cardiac MRI is consistent with myocyte injury and/or scar caused by myocardial inflammation if criterion 3 is present.

C. Repeat cardiac MRI between 1 and 2 weeks after the initial cardiac MRI study is recommended if 
Table 2. Causes and diagnosis of bacterial myocarditis and cardiomyopathy

\begin{tabular}{|c|c|c|}
\hline Bacterial Pathogen & \% Positive in MMR & Diagnosis Made via \\
\hline Staphylococci & $0.03 \%$ & Blood culture, in sepsis or endocarditis \\
\hline Streptococci & $0.02 \%$ & $\begin{array}{c}\text { In rheumatic fever, in cooperation with Chandigarh } \\
\text { microscopy from sputum, pericardial fluid }\end{array}$ \\
\hline Mycobacterium tuberculosis & $0.02 \%$ & Serodiagnosis \\
\hline Haemophilus Influenza & $0.002 \%$ & Serodiagnosis \\
\hline
\end{tabular}

a) None of the criteria are present but onset of symptoms is very recent and there is strong clinical evidence for myocardial inflammation;

b) One of the criteria present.

D. The presence of LV dysfunction or pericardial effusion provides additional supportive evidence for myocarditis.

When $\geq 2$ of the 3 criteria (A to $\mathrm{C}$ ) are positive, myocardial inflammation can be predicted with a diagnostic accuracy of $78 \%$ but if only delayed post-gadolinium enhancement imaging is used, the diagnostic accuracy drops to 68\% [99]. Cardiac MRI has an almost similar accuracy to endomyocardial biopsy. In histopathologic evaluation of biopsy specimen directed with cardiac MRI with delayed enhancement revealed active MC in 19 of 21 patients but when contract could not be obtained from region of contract enhancement, active MC was found in only 1 out of 11 patients [100]. However, the use of cardiac MRI in patients with MC and DCM due to bacterial infection have been described in the setting of viral MC and DCM but their use for primary bacterial MC or CM has not been reported.

\section{Management strategies}

\section{Heart failure therapy}

Pharmacological support : Ideally, the treatment of infective myocarditis should target the causal bacterial pathogen but the effect of aetiology-based therapy has only been confirmed in a few inflammatory heart diseases including sarcoidosis and giant cell MC [2]. Due to a high incidence of impaired LV function in patients with $\mathrm{BCM}$, evidence based HF pharmacotherapy in patients with BMC have been performed but the evidence is based largely on animal models. The 2016 AHA scientific statement on diagnostic and treatment strategies for specific dilated cardiomyopathies and the 2013 ESC position statement on aetiology, diagnosis, management, and therapy of myocarditis [7] recommend intensive pharmacological support for BCM patients diagnosed with hemodynamic instability $[7,101]$. Most patients with acute MC presenting with DCM respond well to standard HF pharmacotherapy: diuretics, angiotensin-converting enzyme inhibitors (ACE-I) or angiotensin receptor blockers (ARBs), and betablockers (bisoprolol, metoprolol succinate, or carvedilol) once they are clinically stable. Standard HF therapy should be initiated according to the New York Heart Association (NYHA).

Early initiation of ACE-I and ARBs has been shown to attenuate chronic maladaptive cardiac remodelling and reduce the progression to DCM. Experimental autoimmune or virus-induced CM mouse models reveal ACE-I (captopril) and ARBs (losartan and olmesartan) reduced inflammation, necrosis and fibrosis while olmesartan significantly improved LV function and reduced progression of cardiac remodelling [102-106]. In a rat model of inflammatory CM, diuretics has been associated with decreased fibrosis, myocyte sizes and myocardial protein levels [107]. Beta-blockers is discouraged in the phase of acute decompensated HF and in early treatment of fulminant MC, although it improved ventricular function and reduces hospitalization for worsening HF and improved survival these effects vary based on the type of beta-blocker used. While carvedilol produces cardioprotective effect (suppress inflammatory cytokines and its antioxidant properties) in rat models of autoimmune MC, metoprolol and propranolol did not show cardioprotective effects [108]. The administration of aldosterone antagonists is recommended for systolic HF patients with persistent NYHA functional class II to IV symptoms. In these patients, aldosterone antagonists in addition of standard HF therapy reduced hospitalization for worsening HF and increased survival [109]. Antiinflammatory effect of Eplerenone on murine viral MC inhibited mastcell derived proteinases resulting in improved myocardial remodelling by suppressing fibrosis [110].

Non-pharmacological support: In a subset of BCM patients presenting with cardiogenic shock, mechanical circulatory (such as extracorporeal membrane oxygenation [ECMO]) supports may be beneficial for adult and paediatric patients with fulminant MC [111,112]. For patients with cardiogenic shock due to acute MC, who deteriorate despite optimal medical management, they are likely to have prolonged recovery and implantation of ventricular assist device (VAD) as a bridge to transplantation $[113,114]$. Cardiac transplantation is reserved for patients who are refractory to both optimal medical management and mechanical circulatory support [1]. Patients presenting with high-grade atrioventricular (AV) block and tachyarrhythmias may require appropriate anti-arrhythmic medication and placement of temporary or permanent pacemaker as needed. Usually, arrhythmias resolve after several weeks. Patients with symptomatic or sustained ventricular tachycardia may require antiarrhythmic therapy or possibly implantable cardioverter-defibrillator (ICD) or heart transplantation if arrhythmias persist after acute inflammatory phase. Finally, due to the evidence of associating sustained aerobic exercise during acute viral MC and increased mortality, patients with acute MC are advised to withdraw from competitive sports and other vigorous exercise for up to six months or longer after the onset of symptoms, with the length of recuperation depending on the recovery of $\operatorname{LV}$ function $[115,116]$. However, the evidence for non-pharmacological support for infective MC and DCM is based on studies on viral aetiologies but their beneficial properties on bacterial aetiologies have not been elucidated.

\section{Antibiotic therapy}

Specific large-scale clinical trials on antibiotic treatment for primary bacterial infection of the myocardium are conspicuously lacking. However, emerging evidence suggest that aggressive antibiotic therapy directed at the suspected or proven bacterial pathogen may be clinically beneficial to BMC patients. Fourier et al. described eight patients with acute $\mathrm{Q}$ fever associated MC treated with antibiotic (doxycycline) for a minimum of 14 days [51]. Five patients fully recovered, two died and one was listed for cardiac transplantation. Vogiatzis et al. described a 30-year old woman infected with C. burnetti presenting with chest pain, ECG abnormalities and higher levels of serum cardiac biomarkers who received doxycycline therapy for 21 days and remained asymptomatic 
for 24 months [117]. Murcia et al. described a similar case of a 40-yearold man with C. burnetti presenting with fever and rapid development of HF symptoms [118]. Treatment with clarithromycin combined with losartan and furosemide completely normalised his cardiac function by six months. Mycoplasma pneumonia responds to macrolide antibiotics. Two case reports describe a young woman with Chlamydia pneumoniae MC presenting with acute HF with polymerase chain reaction (PCR) and Southern blot analysis on myocardial specimen detecting $C$ pneumoniae and parvovirus B19 genomes whose cardiac function normalized and biventricular assist device explanted after a ceftriaxone and erythromycin therapy $[118,119]$. In five patients with mycoplasma pneumonia, MC treated with erythromycin and doxycycline, four experienced a complete recovery including normalization of cardiac structure and function [120]. In addition to antibiotic therapy, if a primary focus of bacteraemia is detected, drainage may be indicated. However, the role of surgical removal or drainage of localized myocardial abscesses remains incompletely defined, although the usual multifocal distribution of tiny abscesses would militate against the effectiveness and feasibility of surgical intervention in most cases [120].

\section{Meta-analysis of siagnosis/management}

Cases of bacterial infection as the primary cause of infective MC and/or DCM has reduced considerably since the advent and widespread use of antibiotics although case reports continue to describe sporadic incidences of BCM [51,117-120]. Reduced incidences has contributed to the lack of large-scale trials limiting a specific understanding of pathophysiology, diagnosis and clinical management of BCM. Besides blood culture and serologic tests that are specific to bacterial infection, diagnosis methods for MC and DCM rely on the evidence from viral MC, which may not apply to bacterial aetiologies $[82,91,92,121]$. In addition, treatment strategies such as pharmacological and non-pharmacological therapies depend on findings from animal models mostly involving viral MC or CM with no available reports of human trials. The efficacy of antibiotics on cardiac function or relief of symptoms has also remained unclear. This meta-analysis therefore evaluates diagnosis and clinical management methods for BCM patients. It was performed using a prospective protocol, which was based on recommended methods for systematic reviews and meta-analyses of observational studies and adverse events [122-124]. Three online databases (PubMed, EMBASE and Cochrane Library) were searched for relevant publications that investigated diagnosis and treatment methods in patients with bacterial MC or CM. Table 3 provides a summary of the fifteen (15) studies included in this and meta-analysis.

\section{Findings}

There was a lack of clinical trials or studies specifically investigating patients with BCM. The 15 studies included in this meta-analysis investigated patients with primary bacterial infection and clinical evidence of cardiac involvement, which included patients with bacterial myocarditis and/or cardiomyopathy [51,63,125-137]. . The studies were published between 1980 and 2018 [63,134-137]. A majority of the studies (two thirds) of the 15 studies were prospective observational cohort studies $(\mathrm{n}=10 ; 67 \%)$ [63,125,127-129, 132,133,135-137], autopsy series $(n=2 ; 13 \%)$, case series $(n=2 ; 13 \%)$ and retrospective

Table 3. Summary of the Characteristics of the Studies Included in the Meta-analysis

\begin{tabular}{|c|c|c|c|c|c|c|c|}
\hline $\begin{array}{l}\text { First Author } \\
\text { [Ref \#] }\end{array}$ & Year & Study Design & $\begin{array}{l}\text { No. of } \\
\text { Patients }\end{array}$ & $\begin{array}{l}\text { Bacterial pathogen } \\
\text { (disease) }\end{array}$ & Diagnostic Methods & $\begin{array}{l}\text { Antibiotic } \\
\text { Therapy }\end{array}$ & Summary of Main Findings \\
\hline Steere $[63]$ & 1980 & $\begin{array}{l}\text { Prospective } \\
\text { cohort }\end{array}$ & 20 & Borrelia (Lyme disease) & $\begin{array}{l}\text { ECG, radionuclide, } \\
\text { serological tests }\end{array}$ & Not evaluated & $\begin{array}{l}\text { Complete heart block is common, with mild } \\
\text { myopericarditis with no involvement of valves }\end{array}$ \\
\hline Lee $[122]$ & 1986 & $\begin{array}{l}\text { Prospective } \\
\text { cohort }\end{array}$ & 11 & $\begin{array}{l}\text { Leptospira (Weil } \\
\text { disease) }\end{array}$ & $\begin{array}{l}\text { ECG, clinical, } \\
\text { serological and } \\
\text { histological tests }\end{array}$ & Not evaluated & $\begin{array}{l}\text { Widespread ST-T wave changes, atrial arrhythmias, } \\
\text { cardiomegaly, interstitial and perivascular inflammatory } \\
\text { infiltrates, and other organs involvement (renal/hepatic) }\end{array}$ \\
\hline Garcia [123] & 1999 & Autopsy series & 31 & $\begin{array}{l}\text { Meningococcus } \\
\text { (Meningitis) }\end{array}$ & $\begin{array}{l}\text { Serological and } \\
\text { histological tests }\end{array}$ & Vasoactive drugs & $\begin{array}{l}\text { High frequency of MC in fatal cases of meningococcal } \\
\text { infection not influenced by medication, sex, age and time } \\
\text { after onset of symptoms }\end{array}$ \\
\hline Fournier [51] & 2001 & Case series & 8 & C. burnetti (Q fever) & $\begin{array}{c}\text { ECG, serological, } \\
\text { blood culture, } \\
\text { histological, and } \\
\text { immuno-histochemical }\end{array}$ & $\begin{array}{l}\text { Doxycycline, } \\
\text { furosemide, } \\
\text { digoxin }\end{array}$ & $\begin{array}{l}\text { Prolonged QTc, T-wave inversion, mononuclear } \\
\text { and lymphocytic infiltrate in the myocardium with } \\
\text { myocardial necrosis. Resolution of symptoms within 1-3 } \\
\text { months }\end{array}$ \\
\hline Dung [124] & 2002 & $\begin{array}{l}\text { Prospective } \\
\text { cohort }\end{array}$ & 32 & $\begin{array}{l}\text { C. Diphtheriae } \\
\text { (Diphtheria) }\end{array}$ & $\begin{array}{l}\text { ECG, serological tests, } \\
\text { echo, }\end{array}$ & $\begin{array}{l}\text { Temporary } \\
\text { cardiac } \\
\text { pacemaker }\end{array}$ & $\begin{array}{l}\text { Major ECG abnormalities - complete heart bloc, and } \\
\text { elevated cardiac kinase and troponin T. Temporary } \\
\text { insertion of cardiac pacemaker may improve outcomes in } \\
\text { in children and adolescents with diphtheric MC }\end{array}$ \\
\hline Trivedi [125] & 2003 & $\begin{array}{l}\text { Prospective } \\
\text { cohort }\end{array}$ & 25 & $\begin{array}{l}\text { Leptospira (Weil } \\
\text { disease) }\end{array}$ & $\begin{array}{c}\text { ECG, echo, serological } \\
\text { tests }\end{array}$ & Not evaluated & $\begin{array}{l}\text { Common ECG abnormality - AV block, prolonged } \\
\text { QTc interval, ventricular premature beats, with no LV } \\
\text { dysfunction on echo. }\end{array}$ \\
\hline Kneen [126] & 2004 & $\begin{array}{l}\text { Prospective } \\
\text { cohort }\end{array}$ & 154 & $\begin{array}{l}\text { C. Diphtheriae } \\
\text { (Diphtheria) }\end{array}$ & ECG, serologic tests & Benzyl penicillin & $\begin{array}{l}\text { ECG and measurement of serum biomarkers of cardiac } \\
\text { damage can predict cardiomyopathy due to diphtheria. In } \\
79 \text { survivors, all had normal ECG after } 1 \text { month }\end{array}$ \\
\hline Salkade [127] & 2005 & Autopsy series & 62 & $\begin{array}{l}\text { Leptospira (Weil } \\
\text { disease) }\end{array}$ & $\begin{array}{c}\text { Serologic tests, } \\
\text { immunohistochemical }\end{array}$ & Not evaluated & $\begin{array}{l}\text { Extra cardiac tissues and organ haemorrhage with } \\
\text { pulmonary haemorrhage being the main cause of death. }\end{array}$ \\
\hline Costello [128] & 2009 & Case series & 207 & Borrelia (Lyme disease) & $\begin{array}{l}\text { ECG, echo, serological } \\
\text { and histological tests }\end{array}$ & $\begin{array}{l}\text { Antibiotics } \\
\text { (atropine, } \\
\text { isoproterenol, } \\
\text { prednisone, } \\
\text { furosemide, } \\
\text { temporary } \\
\text { pacing) }\end{array}$ & $\begin{array}{c}\text { Common ECG abnormalities ST-T changes complete } \\
\text { heart block, LV dysfunction, inflammatory changes on } \\
\text { biopsy. Sinus rhythm and cardiac dysfunction resolved } \\
\text { after } 1 \text { month. }\end{array}$ \\
\hline Kole [129] & 2012 & $\begin{array}{l}\text { Prospective } \\
\text { cohort }\end{array}$ & 100 & $\begin{array}{l}\text { C. Diphtheriae } \\
\text { (Diphtheria) }\end{array}$ & $\begin{array}{c}\text { ECG, blood tests } \\
\text { including cardiac } \\
\text { biomarkers, serological } \\
\text { tests }\end{array}$ & $\begin{array}{l}\text { Intravenous } \\
\text { benzyl penicillin } \\
\text { and ADS }\end{array}$ & $\begin{array}{l}\text { Common ECG abnormalities T-wave inversion, sinus } \\
\text { tachycardia, ST segment depression and heart block. } \\
\text { Increased vaccination and improved socioeconomic } \\
\text { status are effective preventive measures to reduce the } \\
\text { incidence of diphtheric cardiomyopathy }\end{array}$ \\
\hline
\end{tabular}




\begin{tabular}{|c|c|c|c|c|c|c|c|}
\hline $\begin{array}{l}\text { First Author } \\
\text { [Ref \#] }\end{array}$ & Year & Study Design & $\begin{array}{c}\text { No. of } \\
\text { Patients }\end{array}$ & $\begin{array}{l}\text { Bacterial pathogen } \\
\text { (disease) }\end{array}$ & Diagnostic Methods & $\begin{array}{l}\text { Antibiotic } \\
\text { Therapy }\end{array}$ & Summary of Main Findings \\
\hline $\begin{array}{l}\text { G u n a s e } \mathrm{k} \text { ar a } \mathrm{n} \\
{[130]}\end{array}$ & 2016 & $\begin{array}{l}\text { Prospective } \\
\text { cohort }\end{array}$ & 81 & $\begin{array}{l}\text { R. tsutsugamuschi } \\
\text { (Scrub Typhus) }\end{array}$ & $\begin{array}{c}\text { ECG, echo, blood tests, } \\
\text { serological tests, }\end{array}$ & Not evaluated & $\begin{array}{l}\text { Non-specific ECG changes, sinus tachycardia was the } \\
\text { most common. In scrub typhus, cardiac manifestation } \\
\text { are frequently associated with increased morbidity and } \\
\text { mortality. }\end{array}$ \\
\hline Chin [131] & 2018 & $\begin{array}{l}\text { Retrospective } \\
\text { cohort }\end{array}$ & 89 & $\begin{array}{l}\text { R. tsutsugamuschi } \\
\text { (Scrub Typhus) }\end{array}$ & $\begin{array}{c}\text { ECG, echo, cardiac } \\
\text { biomarkers and } \\
\text { coronary angiography }\end{array}$ & Not evaluated & $\begin{array}{l}\text { High incidence of ST elevation, paroxysmal atrial } \\
\text { fibrillation were common in patients with MC than those } \\
\text { without. Patients with high bilirubin and atrial fibrillation } \\
\text { are at an increased risk of acute MC associated with } \\
\text { scrub typhus. }\end{array}$ \\
\hline Karthik [132] & 2018 & $\begin{array}{l}\text { Prospective } \\
\text { cohort }\end{array}$ & 81 & $\begin{array}{l}\text { R. tsutsugamuschi } \\
\text { (Scrub Typhus) }\end{array}$ & $\begin{array}{c}\text { ECG, echo, serological } \\
\text { tests and blood tests }\end{array}$ & Not evaluated & $\begin{array}{l}\text { In scrub typhus disease, cardiac manifestations are } \\
\text { frequent and associated with increased mortality }\end{array}$ \\
\hline Melenotte [133] & 2018 & $\begin{array}{l}\text { Prospective } \\
\text { cohort }\end{array}$ & 2434 & C. burnetti ( $Q$ fever $)$ & $\begin{array}{c}\text { ECG, echo, } \\
\text { histological tests, }\end{array}$ & Not evaluated & $\begin{array}{l}\text { Routine screening forl antibodies can help reduce } \\
\text { complications and to diagnose vascular and lymphatic } \\
\text { infections associated with death and lymphoma. }\end{array}$ \\
\hline Samdani [134] & 2018 & $\begin{array}{l}\text { Prospective } \\
\text { cohort }\end{array}$ & 60 & $\begin{array}{l}\text { C. Diphtheriae } \\
\text { (Diphtheria) }\end{array}$ & $\begin{array}{c}\text { ECG, serologic testing } \\
\text { and blood tests for } \\
\text { serum biomarkers }\end{array}$ & $\begin{array}{c}\text { Intravenous ADS, } \\
\text { benzyl penicillin } \\
\text { and oral } \\
\text { erythromycin }\end{array}$ & $\begin{array}{c}\text { Sinus tachycardia, T-wave inversion, ST segment } \\
\text { depression, RBBB, multiple atrial ectopic. Cardiac } \\
\text { involvement is a common complication of diphtheria } \\
\text { associated with high mortality but preventable with } \\
\text { adequate vaccination. Symptoms resolve within 4-6 } \\
\text { weeks. }\end{array}$ \\
\hline
\end{tabular}

cohort $(\mathrm{n}=1 ; 7 \%)[51,126,130,131,134]$. In total, the 15 studies included 3,395 patients with suspected or confirmed bacterial MC or $\mathrm{CM}$. The studies included both children and adults, with a mean age of 35 years. A greater majority were male patients (64\%) reported in 13 studies [51,63,125,126,128-136]. Bacterial infections (and primary disease) studied included borrelia (Lyme disease) [63,31], leptospira (Weil disease), meningococcus (meningitis) [126], C. burnetti ( $\mathrm{Q}$ fever), C. diphtheriae (diphtheria), and R. tsutsugamuschi (scrub typhus) [31,51,63,125,128-130,133-135].

Clinical presentation could not be pooled because of insufficient data and wide variation across studies due to heterogeneity of causative bacterial pathogens. However, common signs and symptoms in almost all the 15 studies included chest pain, new-onset or worsening dyspnoea, palpitations, unexplained arrhythmias and unexplained cardiogenic shock. Common diagnostic tests performed in almost all the 15 studies were serological tests and EMB (histological and/ or immunohistochemical tests) to diagnose the causative bacteria pathogen, and ECG, cardiac biomarkers, and echocardiography to evaluate cardiac involvement. ECG was performed in all cohort studies and case series (apart from autopsy series) to detect abnormalities in the heart's conduction system. Data from eight studies revealed ECG abnormalities occurred in $68.4 \%$ of the patients (95\% CI: $38.8 \%$ to $88.1 \%$ ) (Figure 1) [63,125,127-129,131,132,137]. However, there was significant heterogeneity $\left(I^{2}=96.05 \%\right)$ across individual studies attributed to differences in the characteristics of patients enrolled, which included those with or without echocardiographic evidence of cardiac dysfunction, age differences (included children and adults) and differences in the time ECG test was performed since the onset of the disease. Further analysis showed common electrical conduction abnormalities were T-wave inversion (29.8\%; 95\% CI: $13.9 \%$ to $52.7 \%$; Figure 2), ST/T-wave changes (20.2\%; $95 \%$ CI: $9.4 \%$ to $38.3 \%$; Figure 3), ST-segment elevation (17.3\%; 95 CI: $6.8 \%$ to $37.6 \%$; Figure 4 ), STsegment depression (13.3\%; $95 \%$ CI: $6.8 \%$ to $24.5 \%$; Figure 5), prolonged QT interval (9.8\%; 95 CI: $2.1 \%$ to $35.2 \%$; Figure 6). Other common ECG abnormalities included sinus tachycardia (35.9\%; $95 \%$ CI: $20.7 \%$ to $54.6 \%$; Figure 7 ) and heart block (36.2\%; $95 \%$ CI: $28.3 \%$ to $44.9 \%$; Figure 8). In addition to ECG tests, echocardiography was performed to evaluate cardiac dysfunction. Five studies [51,63,125,127,128,135] reported echocardiography findings of cardiac abnormalities in $36.2 \%$ of the patients (95\% CI: $15.6 \%$ to $63.5 \%$; Figure 9).

\section{Event Rate and $95 \% \mathrm{Cl}$ for ECG Abnormalities}

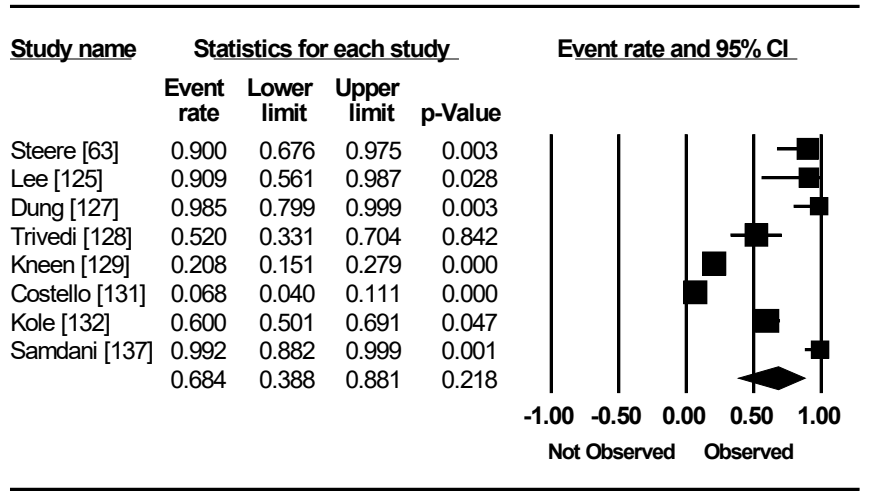

Test for heterogeinity: $I^{\wedge} 2=96.05 \% ; p=0.000$

Figure 1. Forest Plot of Event Rate for ECG Abnormalities

Event Rate and 95\% Cl for T-wave Inversion

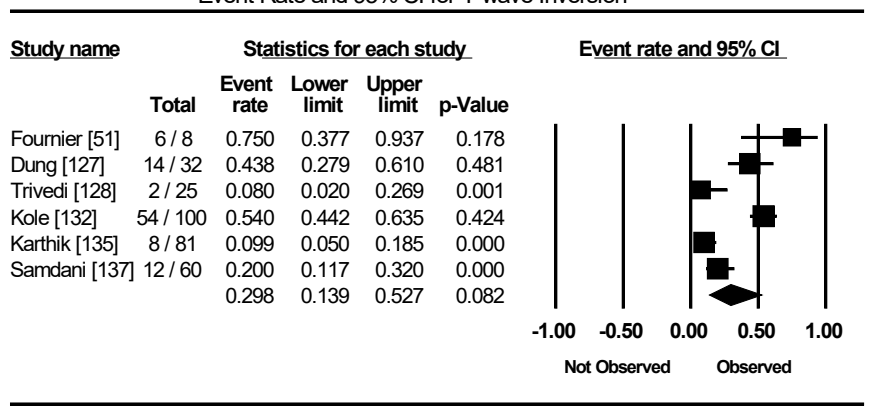

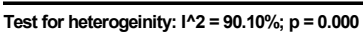

Figure 2. Forest Plot of Event Rate for T-Wave Inversion

The effect of treatment strategies (antibiotics or HF therapy) on clinical outcomes such as symptom resolution, improvement of cardiac function, hospitalization and deaths could not be established because of either the lack of data or the lack of control or placebo patients for comparison. However, deaths occurred in $14.3 \%$ of the patients (95\% CI: $4.7 \%$ to $36.0 \%$; Figure 10). For alive patients, resolution of symptoms of bacterial infection and improvement in cardiac function occurred within one to three months after the commencement or the completion of antibiotic therapy. Pooled analysis of HF therapy on BCM 
Event Rate and 95\% Cl for ST/T-Wave Changes

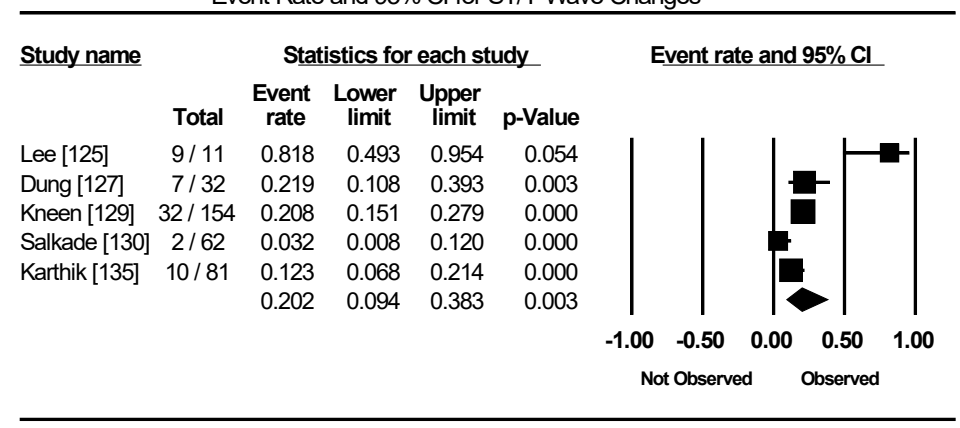

Test for heterogeinity: $1^{\wedge} 2=83.62 ; p=0.000$

Figure 3. Forest Plot of Event Rate for ST-T Wave Changes

Event Rate and 95\% Cl for ST-Segment Elevation

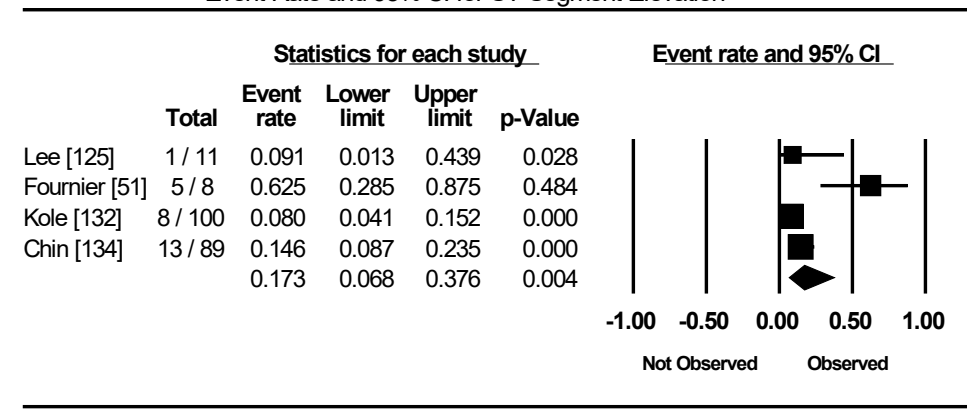

Test for heterogeinity: $I^{\wedge} 2=77.41 \% ; p=0.004$

Figure 4. Forest Plot of Event Rate for ST-Segment Elevation

Event Rate and 95\% Cl for ST-Segment Depression

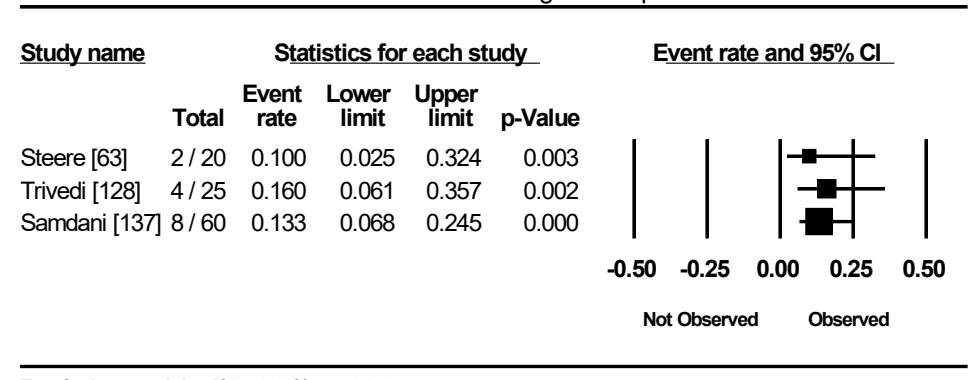

Test for heterogeinity: $I^{\wedge} 2=0.00 \% ; p=0.843$

Figure 5. Forest Plot of Event Rate for ST-Segment Depression

Event Rate and 95\% Cl for Prolonged QT Interval

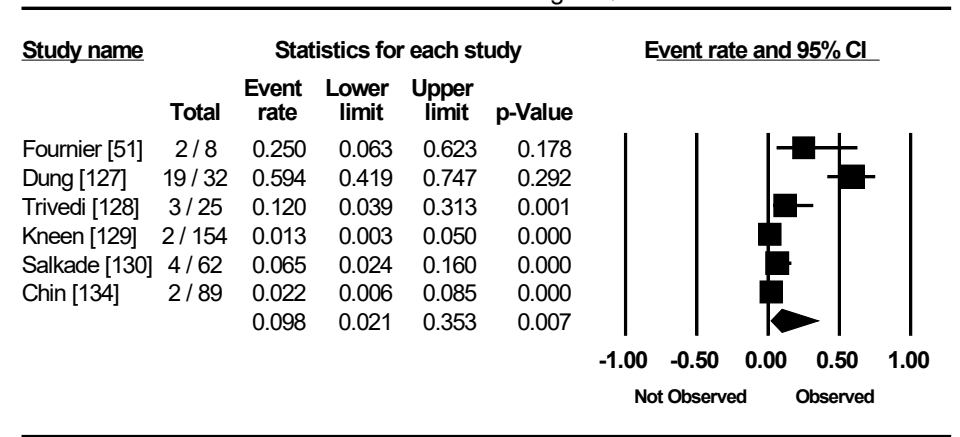

Test for heterogeinity: $I^{\wedge} 2=91.56 \% ; p=0.000$

Figure 6. Forest Plot of Event Rate for Prolonged QT-Interval 
Event Rate and 95\% Cl for Sinus Tachycardia

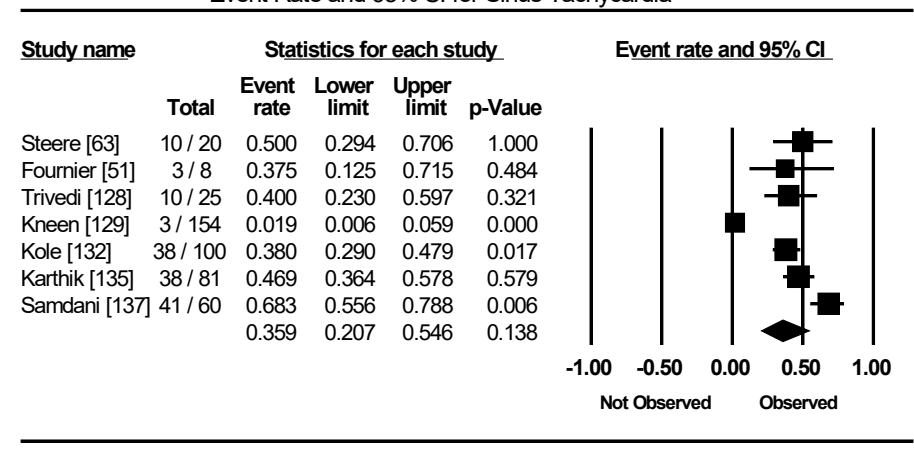

Test for heterogeinity: $I^{\wedge} 2=89.16 \% ; p=0.000$

Figure 7. Forest Plot of Event Rate for Sinus Tachycardia

Event Rate and 95\% Cl for Heart Block

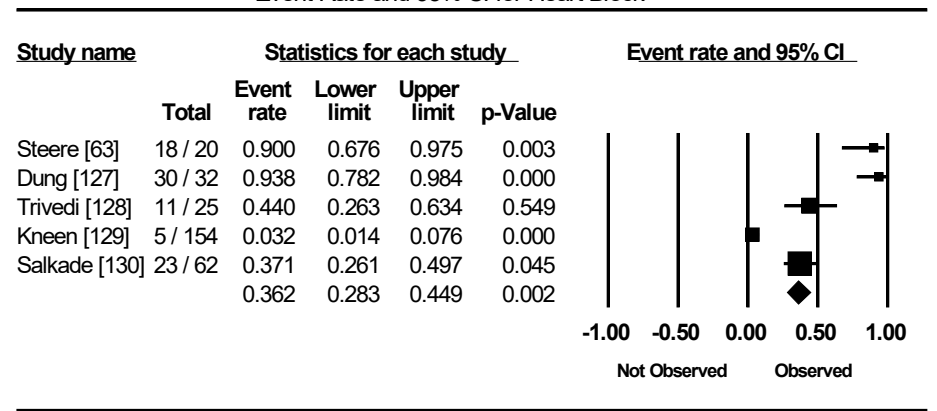

Test for heterogeinity: $\wedge^{\wedge} 2=95.54 \% ; p=0.000$

Figure 8. Forest Plot of Event Rate for Heart Block

Event Rate and $96 \% \mathrm{Cl}$ for Echocardiographic Abnormalities

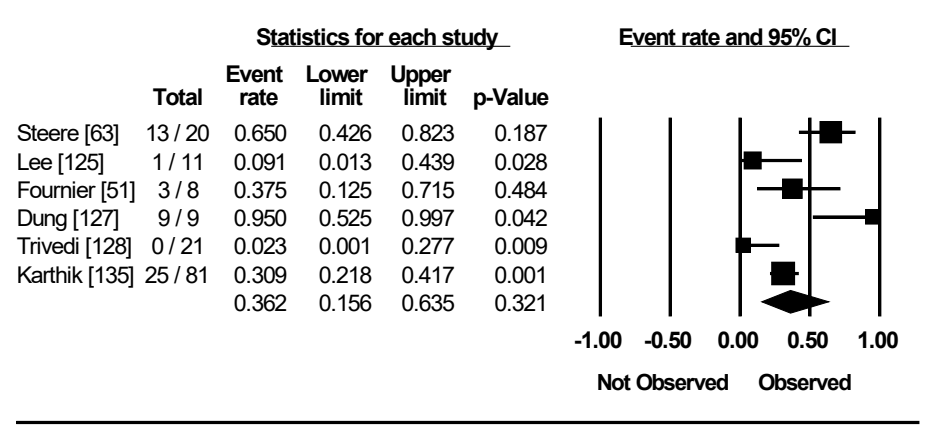

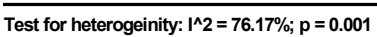

Figure 9. Forest Plot of Event Rate for Echocardiographic Abnormalities

Event Rate and $95 \% \mathrm{Cl}$ for Deaths

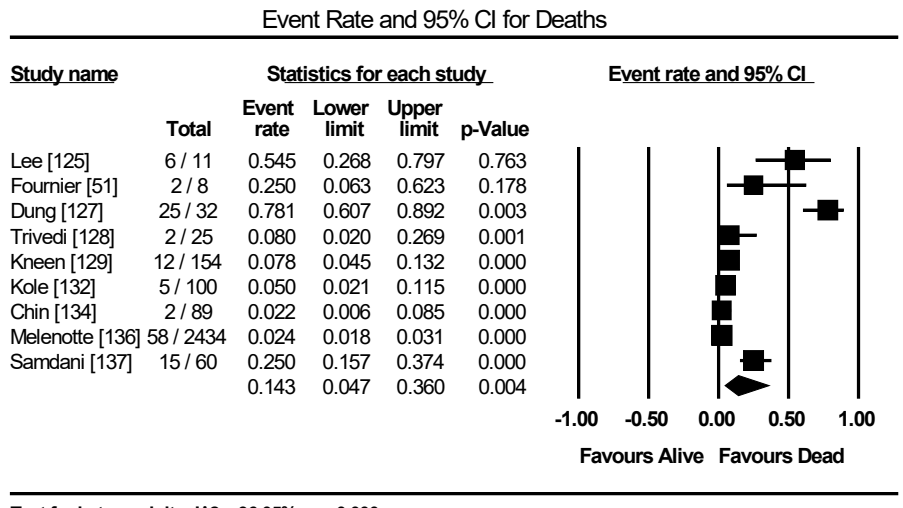

Test for heterogeinity: $I^{\wedge} 2=96.05 \% ; p=0.000$

Figure 10. Forest Plot of Event Rate for Deaths 
patients could not be calculated because of the lack of data. Only one study evaluated the effect of temporary cardiac pacemaker on survival of children and adolescent patients with diphtheric myocarditis and severe conduction abnormalities [127]. The study and reported $26 \%$ survival in the pacemaker group compared to $0 \%$ in the group without pacemaker (mean difference $26 \%$; $95 \%$ CI: $9 \%$ to $42 \%$ ). None of the studies used cardiac magnetic resonance imaging on patient selection nor assessed its utility in the diagnosis of cardiac dysfunction in patients with bacterial infection and suspected cardiac involvement. Finally, data on signs and symptoms could not be pooled because of wide heterogeneity in clinical presentation associated with many several causative bacterial pathogens the underlying primary disease.

\section{Discussion}

Infective MC is a clinical syndrome marked with myocardial inflammation with heterogeneous aetiologies including viral, bacterial, fungal and protozoal. Bacterial aetiologies are rare and potentially reversible but if undiagnosed or left untreated, ongoing infection, myocardial injury and adverse remodelling may lead to persistent ventricular dysfunction, DCM, HF and death $[1,34]$. Current expert consensus guidelines recommend diagnostic criteria of BCM should include a combination of clinical presentation and/or non-invasive evidence of abnormal cardiac function and/or structure are key criteria in the diagnosis of BCM $[7,99,101]$. Similar to these recommendations, the findings of the present meta-analysis indicate that clinical presentation, ECG abnormalities, elevated cardiac biomarkers and non-invasive evidence of cardiac dysfunction could be used to support the diagnosis of $\mathrm{BCM}$ after serologic tests have confirmed the presence of bacterial infection. The present meta-analysis finds that the most common clinical manifestations in BCM patients are chest pain, a newonset or worsening dyspnoea, palpitations, unexplained arrhythmia and unexplained cardiogenic shock. In addition to clinical presentation, important diagnostic features include ECG abnormalities, elevated cardiac biomarkers, and non-invasive evidence of cardiac dysfunction. Finally, in the present findings, the use of HF and antibiotic therapy appear to improve cardiac function and relieve symptoms but its effect on hard clinical endpoints such as hospitalization and death were not been evaluated due to the lack of sufficient data.

\section{Clinical manifestation}

Pooled analysis of clinical signs and symptoms of BCM patients could not be calculated due to the lack of sufficient data provided in individual studies. However, individual studies suggest clinical manifestation is highly variable, ranging from asymptomatic febrile illness and ECG abnormalities to HF, cardiogenic shock and death. In addition, most of the cases of BCM were subclinical, suggesting patients may infrequently seek medical attention during acute illness. Despite the variability, the common signs and symptoms associated with BCM were fever, chest-pain, dyspnoea, syncope, palpitations, unexplained arrhythmias and unexplained cardiogenic shock. Although these signs and symptoms are non-specific to bacterial MC or DCM, they are useful in raising clinical suspicion to warrant additional diagnostic tests.

The present findings of the common signs and symptoms of BCM are consistent with those reported in previous studies, reviews and expert consensus on diagnosis and treatment of MC and DCM, which include chest pain, dyspnoea, palpitations, fatigue, and decreased exercise tolerance. These signs and symptoms are however non-specific, partly attributed to the wide heterogeneity in causative bacterial pathogens that may result into a wide spectrum of clinical presentation $[99,120]$. In particular, chest pain is a common clinical presentation but non-specific because it may mimic typical angina [138]. Chest pain may also be more typical in patients with pericarditis suggesting pericardial involvement. The European Study of the Epidemiology and Treatment of Cardiac Inflammatory Disease (ESET-CID), which enrolled 3,055 adult patients with suspected acute or chronic myocarditis, also reported similar clinical presentation. Patients with acute or chronic MC presented with dyspnoea (72\%), chest pain (32\%) and arrhythmias (18\%) while patients with fulminant MC typically presented with severe HF symptoms, which may rapidly progressing into cardiogenic shock [139].

Besides variable bacterial aetiologic agents, clinical presentation in BCM patients may also vary with the age of onset of the disease, which shows a bimodal age distribution in the general population. New-borns and infants show infection that is more acute with severe symptoms. Infants have non-specific symptoms such as anxiousness malaise, fever, poor appetite, tachycardia, tachypnoea, and abdominal pain while children $>2$ years may exhibit chest pain, abdominal pain, cough and oedema [140,141]. In contrast, older adults may present with symptoms that are more subtle and insidious, often with DCM and HF. Clinical presentation shows disproportional gender imbalance, with a slight preponderance in male patients. The male to female ratio is 1.5 to 1 , possibly related to a protective effect of the natural hormone variations on immune responses in women. The variable clinical variation in part may reflect variability in histological disease severity, which may be focal or diffuse with the latter resulting in clinical manifestation of acute DCM [140,141].

\section{Electrocardiographic abnormalities}

Cardiac involvement associated with bacterial infection may result in conduction system (ECG) abnormalities due to acute inflammation of the sinoatrial and atrioventricular nodes [137]. In patients with subclinical disease, ECG abnormalities are usually transient and their detection depends on the time of assessment. In the present metaanalysis, ECG abnormalities occurred in $68.4 \%$ of BCM patients but the rate was non-significant $(\mathrm{p}=0.218)$. In particular, ECG abnormalities include T-wave inversion, ST-segment elevation or depression and prolonged QT interval. Sinus tachycardia and heart block were also common ECG findings suggesting cardiac dysfunction. Consistent with the present findings, previous studies report ECG abnormalities are common in MC patients but with a low sensitivity (47\%) with nonspecific T-wave being the most common [88]. A gradual increase in the width of the QRS complex may suggest exacerbation of MC. Frequent premature beats, supraventricular tachycardia and atrial fibrillation may occur in BMC patients, which usually suggest poor prognosis, with increased risk of death. Thus, serial ECG monitoring is important in the management of BCM patients to detect potentially fatal arrhythmias [34].

In BCM patients, ECG abnormalities are usually transient and non-specific. In particular, ECG abnormalities observed in MC patients such as ST-segment elevation, ST-segment depression, PR depression and pathologic Q-waves may mimic ECG changes observed in patients with acute myocardial infarction or pericarditis $[142,143]$. Other common ECG changes include a new-onset supraventricular or ventricular arrhythmias, which have been shown to occur in up to $55 \%$ of patients referred to hospitals with MC or DCM [144]. These tachyarrhythmias are usually non-sustained and rarely result in hemodynamic compromise. ECG abnormalities such as abnormal QRS complexes, northwest axis deviation or new left bundle branch block has been associated with unfavourable prognosis including higher rates of death or heart transplantation $[90,88,145,146]$. These ECG changes 
could be due to pathologic effect of acute coronary arteritis on the main branches of the coronary arteries. An earlier autopsy series revealed the involvement of the heart and main vessels during the septicaemia phase of bacterial infection and bacterial dissemination, toxins, enzymes and/ or antigenic products liberated by bacterial lysis may account for the observed conduction abnormalities [145,146].

\section{Evidence of cardiac dysfunction}

Non-invasive evidence of cardiac dysfunction is one of the key diagnostic criteria for BCM besides clinical presentation and ECG abnormalities. Although current guidelines recommend cardiac MRI for non-invasive assessment for cardiac function, the present metaanalysis finds the utility of echocardiography in the diagnosis of BCM is common and detects cardiac abnormalities in $36.2 \%$ of the patients. In HF patients, echocardiography is a widespread and useful for evaluating cardiac chamber sizes, wall thickness, systolic and diastolic functions as well as the presence of intracavity thrombi [120]. However, in patients with CM and biopsy proven MC, echocardiography lacks pathognomonic diagnostic features to confirm diagnosis [147]. LV systolic dysfunction is common but RV dysfunction is relatively uncommon although clinically important since it is an independent predictor of death or the need for cardiac transplantation in CM patients with biopsy proven MC $[148,149]$. Segmental or global wall motion abnormalities are common in BCM patients but are non-specific since they mimic myocardial infarction [150]. Patients with fulminant $\mathrm{MC}$ tend to present with small cardiac chambers and thickened walls while those with acute MC have marked LV dilation and normal wall thickness [91]. Despite the present findings supporting the use of echocardiography, diagnostic accuracy of cardiac MRI has been shown to be comparable to endomyocardial biopsy [100].

\section{Heart failure and antibiotic therapy}

The safety and efficacy of pharmacological therapy in viral MC has been demonstrated in experimental animal models but has not been validated in humans and in patients with BCM. Similarly, the present analysis did not evaluate the safety and efficacy of the standard HF therapy on BCM patients because of the lack of data in individual studies. In experimental murine models of infective viral $\mathrm{MC}$ and DCM suggest ACE-I and ARBs, and beta-blockers can prevent or even reverse maladaptive cardiac remodelling as well as reduce HF hospitalization and increased survival [103,104,107-109]. However, the effect on HF therapy on BCM in both animals and humans. Device therapy for HF in BCM patients has also not been evaluated although the use of temporary pacemaker has been suggested to improved survival in BCM patients with severe conduction abnormalities when compared to patients without pacemaker (mean difference: $26 \%$; $95 \%$ CI, $9 \%$ to $42 \%$ ) [127]. On the other hand, five studies included in the present meta-analysis suggested positive effect of antibiotic therapy on reducing the concentration of bacteria and improving cardiac function $[51,129,131,132,137]$. Antibiotic therapy (doxycycline, furosemide, benzyl penicillin, isoproterenol, prednisone, furosemide, atropine or erythromycin) appeared to be both safe and effective in minimizing or eliminating bacteria with concomitant benefits of improvement in cardiac function and resolution of symptoms within 1 to 3 months. While $14.3 \%$ of deaths were reported, the number included all study patients including those who received or did not receive antibiotics, or received antibiotics in addition to HF therapy.

\section{Limitations}

Several issues may impair the applicability of the present results to the general population. The included studies revealed difficulties in obtaining well-defined study populations. Incidences of BCM are rare, which create difficulties in identifying appropriate and sufficient prospective patient samples. The included studies enrolled patients with evidence of bacterial infection with or without evidence of cardiac involvement as well as patients with BCM while two were autopsy series. In addition, echocardiography was not performed in all the enrolled patients to confirm cardiac dysfunction, and in patients whom echocardiography was performed, the evidence is non-specific to BCM resulting in the risk of inclusion of patients without BCM. Findings from the present results should also be interpreted with caution due to significant clinical heterogeneity between studies regarding patient population, diagnostic methods used, and antibiotics used. In addition, the enrolled patients consisted of children and adults, which may affect the findings since BMC shows bimodal age distribution in the general population. Data was also insufficient to determine the effect of sex on clinical presentation and outcomes. Finally, the design of the included studies were observation cohort and case series, which increases the possibility of confounding and selection bias during patient enrolment. Selection bias may have been compounded by insufficient description of patients lost to follow-up or died.

\section{Implication for practice and research}

$\mathrm{BCM}$ is a potentially life-threatening disease, which primarily affects children and young adults with sometimes devastating consequences including chronic HF and death. Although much progress has been made over recent years in the diagnosis and treatment of $\mathrm{BCM}$, numerous questions remain indicating the need for further investigation. Serological tests (and sometimes endomyocardial biopsy) are important tests for the diagnosis of the causative bacterial pathogen in patients with a primary bacterial infection and disease. In the setting of bacteraemia and sepsis, signs and symptoms of chest pain, dyspnoea, palpitation, syncope and/or arrhythmias raise the clinical suspicion of cardiac involvement and suspicion for infective MC or DCM.

The presence of ECG abnormalities, elevated levels of cardiac biomarkers (creatinine kinase and troponin), and non-invasive evidence of cardiac dysfunction support the diagnosis of BCM. Noninvasive imaging techniques for confirming the diagnosis of $\mathrm{BCM}$ including cardiac MRI are promising in viral CM but require additional validation in BCM patients including the assessment of myocardial abscesses. Creatinine kinase and troponin are useful biomarkers for diagnosis of BMC but are non-specific. Thus, the identification of novel biomarkers for cardiac inflammation in peripheral blood, analysis of messenger RNA and specific proteins is ongoing [188]. If serum biomarkers with high sensitivity and specificity can be developed as a non-invasive diagnostic method, the use of EMB will decrease. Research on pathophysiology of BCM in humans including cellular processes contributing to myocardial injury remains limited although additional research efforts may lead to novel treatment strategies with pathway specific targets.

Finally, the widespread use of antibiotic therapy and vaccination for bacterial infections has resulted in significant reduction in the incidences of MC and DCM secondary to bacterial infection. Given the low incidence of MC and DCM and the cost of developing novel therapies, it may be doubtful that novel therapies to combat BCM will be developed in the near future. Nevertheless, the effect of conventional HF medication and antibiotic therapy in patients with viral CM and DCM appear to improve cardiac function and relieve symptoms but validation is required for BCM patients including outcomes in hard clinical endpoints of hospitalization, HF and death. Large multi-centre trials are required to ensure sufficient number of end-points as well as 
try to confirm the current promising results from observational studies and case series.

\section{Conclusion}

Primary bacterial infection of the myocardium is a devastating complication of bacteraemia and sepsis, and an uncommon cause of myocarditis (MC) and its sequela bacterial cardiomyopathy (BCM). Infection by a broad range of bacterial pathogens may cause BCM but Staphylococcus aureus is the most common aetiological agent. Others include streptococcus, meningococcus, salmonella, haemophilus influenzae, corynebacterium diphtheria, mycoplasma pneumoniae, gonococcus, brucella and mycobacterium. Rickettsia and spirochaetal are also known bacterial causes of BCM. The exact pathophysiological mechanisms and sequence remains unknown although multi-focal abscesses in the myocardium and extra cardiac organs (lungs, adrenal glands, thyroid glands and parietal pericardium) in the presence of bacteraemia and sepsis, with or without co-existing infective pericarditis are common pathophysiological features. Clinical presentation varies widely from subclinical disease to fulminant HF but often dominated by symptoms and signs of overwhelming infection or by manifestations of cardiac involvement. The current criteria for diagnosis is a combination of clinical presentation, ECG abnormalities, and/or non-invasive evidence of cardiac dysfunction. Serological tests and endomyocardial biopsy are useful for diagnosis of the causative bacterial pathogen, while elevated serum levels of cardiac biomarkers support diagnosis. Recommended therapies include conventional HF therapy to treat cardiac dysfunction; antiarrhythmic drugs to treat arrhythmias; and/ or antibiotic therapy to treat bacterial infection are common therapy. However, the current diagnostic and treatment methods largely rely on the evidence from patients with viral cardiomyopathy, which warrants additional studies to confirm their clinical value in patients with BCM.

\section{References}

1. Blauwet LA, Cooper LT (2010) Myocarditis. Prog Cardiovasc Dis 52: 274-288. [Crossref]

2. Kindermann I, Barth C, Mahfoud F, Ukena C, Lenski M et al. (2012) Update on myocarditis. J Am Coll Cardiol 59: 779-792. [Crossref]

3. Maron BJ, Towbin JA, Thiene G, Antzelevitch C, Corrado D, et al. (2006) Contemporary definitions and classification of the cardiomyopathies: an American Heart Association scientific statement from the council on clinical cardiology, heart failure and transplantation committee; quality of care and outcomes research and functional genomics and translational biology interdisciplinary working groups; and council on epidemiology and prevention. Circulation. 113: 1807-1816. [Crossref]

4. Elliott P, Andersson B, Arbustini E, Bilinska Z, Cecchi F, et al. (2008) Classification of the cardiomyopathies: a position statement from the European society of cardiology working group on myocardial and pericardial diseases. Eur Heart $J$ 29: 270-276. [Crossref]

5. Crum-Cianflone NF (2008) Bacterial, fungal, parasitic, and viral myositis. Clin Microbiol Rev 21: 473-494. [Crossref]

6. Wasi F, Shuter J (2003) Primary bacterial infection of the myocardium. Front Biosci. F 8: s228-231. [Crossref]

7. Caforio AL, Pankuweit S, Arbustini E, Basso C, Gimeno-Blanes J, et al. (2013) Current state of knowledge on aetiology, diagnosis, management, and therapy of myocarditis: a position statement of the European society of cardiology working group on myocardial and pericardial diseases. Eur Heart J 34: 2636-2648. [Crossref]

8. Tagg JR, Dajani AS, Wannamaker LW (1976) Bacteriocins of gram-positive bacteria. Bacteriological reviews 40: 722-756. [Crossref]

9. McGee M, Shiel E, Brienesse S, Murch S, Pickles R, et al. (2018) Staphylococcus aureus myocarditis with associated left ventricular apical thrombus. Case Rep Cardiol. [Crossref]

10. Flaxman N (1943) Myocardial abscess. JAMA 122: 804-806.
11. Sanson J, Slodki S, Gruhn JG (1963) Myocardial abscesses. Am Heart J 66: 301-308. [Crossref]

12. LeLeiko RM, Bower DJ, Larsen CP (2008) MRSA-associated bacterial myocarditis causing ruptured ventricle and tamponade. Cardiology 111: 188-190. [Crossref]

13. Khan B, Strate RW, Hellman R (2007) Myocardial abscess and fatal cardiac arrhythmia in a hemodialysis patient with an arterio-venous fistula infection. Seminars in Dialysis 20: 452-454. [Crossref]

14. Reichardt P, Dähnert I, Tiller G, Häusler HJ (2002) Possible activation of an intramyocardial inflammatory process (Staphylococcus aureus) after treatment with infliximab in a boy with Crohn disease. Eur J Pediatr 161: 281-283. [Crossref]

15. Hofman P, Michiels JF, Rosenthal E, Tran AT, Taillan B et al. (1993) Acute Staphylococcus aureus myocarditis in AIDS. 2 cases. Archives des Maladies du Coeur et des Vaisseaux 86: 1765-1768. [Crossref]

16. Spellerberg B, Brandt C (2015) Streptococcus. In Manual of Clinical Microbiology, Eleventh Edition (pp. 383-402) American Society of Microbiology.

17. Patterson MJ (1996) Streptococcus. InMedical Microbiology. 4th edition. University of Texas Medical Branch at Galveston. [Crossref]

18. Chikly A, Durst R, Lotan C, Chen S (2014) Recurrent acute nonrheumatic streptococca myocarditis mimicking STEMI in a young adult. Case reports in cardiology 2014. [Crossref]

19. Chaudhuri A, Dooris M, Woods ML (2013) Non-rheumatic streptococcal myocarditiswarm hands, warm heart. J Med Microbiol 62: 169-172. [Crossref]

20. Gore I, Saphir O (1947) Myocarditis: a classification of 1402 cases. Am Heart J 34 827-830. [Crossref]

21. Tzeng YL, Stephens DS (2000) Epidemiology and pathogenesis of Neisseria meningitidis. Microbes and infection 2: 687-700. [Crossref]

22. Rosenstein NE, Perkins BA, Stephens DS, Popovic T, Hughes JM (2001) Meningococcal disease. N Eng J Med 344: 1378-1388. [Crossref]

23. Guarner J, Greer PW, Whitney A, Shieh WJ, Fischer M, et al. (2004) Pathogenesis and diagnosis of human meningococcal disease using immunohistochemical and PCR assays. Am J Clin Pathol 122: 754-764. [Crossref]

24. Bohm N (1982) Adrenal, cutaneous and myocardial lesions in fulminating endotoxinemia (Waterhouse-Friderichsen syndrome). Pathol Res Pract 174: 92-105. [Crossref]

25. Lin VH, Parekh RS, McQuillan MA, Braun DK, Markovitz DM (1995) Meningococcal endocarditis presenting as cellulitis. Clin Infect Dis 21: 1023-1025. [Crossref]

26. Hardman JM, Earle KM (1969) Myocarditis in 200 fatal meningococcal infections Arch. Pathol 87: 318-325. [Crossref]

27. Feldman AM, McNamara D (2000) Myocarditis. $N$ Eng $J$ Med 343: 1388-1398 [Crossref]

28. Saphir O (1936) Meningococcus myocarditis. Am J Pathol 12: 677-687. [Crossref]

29. Brasier AR, Macklis JD, Vaughan D, Warner L, Kirshenbaum JM (1987) Myopericarditis as an initial presentation of meningococcemia: unusual manifestation of infection with serotype W135. Am J Med 82: 641-644. [Crossref]

30. Abela GS, Majmudar B, Felner JM (1981) Myocardial abscesses unassociated with infective endocarditis. Southern Medical Journal 74: 432-434. [Crossref]

31. Gordon MA (2008) Salmonella infections in immunocompromised adults. J Infect 56: 413-422. [Crossref]

32. Dhanoa A, Fatt QK (2009) Non-typhoidal Salmonella bacteraemia: epidemiology, clinical characteristics and its' association with severe immunosuppression. Ann Clin Microbiol Antimicrob 8: 15. [Crossref]

33. Villablanca P, Mohananey D, Meier G, Yap JE, Chouksey S, et al. (2015) Salmonella Berta myocarditis: Case report and systematic review of non-typhoid Salmonella myocarditis. World J Cardiol 7: 931-937. [Crossref]

34. Calabrese F, Thiene G (2003) Myocarditis and inflammatory cardiomyopathy: microbiological and molecular biological aspects. Cardiovas Res 60: 11-25. [Crossref]

35. Ukimura A, Izumi T, Matsumori A (2010) A national survey on myocarditis associated with the 2009 influenza A (H1N1) pandemic in Japan. Jpn Circ J. [Crossref]

36. Kawaguchi R, Miyazono M, Noda T, Takayama Y, Sasai Y, et al. (2009) H. Influenza (H1N1) 2009 outbreak and school closure, Osaka Prefecture, Japan. Emerg Infect Dis 15: 1685. [Crossref] 
37. Shimada T, Gu Y, Kamiya H, Komiya N, Odaira F, et al. (2009). Epidemiology of influenza A (H1N1) v virus infection in Japan, May-June 2009. Eurosurveillance 14: 19244. [Crossref]

38. Karjalainen J (1990) A loud third heart sound and asymptomatic myocarditis during Mycoplasma pneumoniae infection. Eur Heart J 11: 960-963. [Crossref]

39. Huh KR, Kim JK, Joo NR, Kim JY, Kim Y, et al. (2008) A case of myocarditis and pneumonia caused by Mycoplasma pneumoniae. Korean Journal of Medicine 75: 898903.

40. Bunker D, Kerr LD (2015) Acute myopericarditis likely secondary to disseminated gonococcal infection. Case Rep Infect Dis. 2015. [Crossref]

41. Abid L, Frikha Z, Kallel S, Chokri Z, Ismahen B, et al. (2012) Brucella Myocarditis: A rare and life-threatening cardiac complication of Brucellosis. Intern Med 51: 901-914. [Crossref]

42. Cowley A, Dobson L, Kurian J, Saunderson C (2017) Acute myocarditis secondary to cardiac tuberculosis: A case report. Echo research and practice 4: K25-K29. [Crossref]

43. Shah SS, McGowan JP (2003) Rickettsial, ehrlichial and Bartonella infections of the myocardium and pericardium. Front Biosci 8: e197-201. [Crossref]

44. Doyle A, Bhalla KS, Jones III JM, Ennis DM (2006) Myocardial involvement in rocky mountain spotted fever: a case report and review. Am J Med Sci 332: 208-210. [Crossref]

45. Bradford WD, Hackel DB (1978) Myocardial involvement in rocky mountain spotted fever. Arch Pathol Lab Med 102: 357-359. [Crossref]

46. Walker DH, Paletta CE, Cain BG (1980) Pathogenesis of myocarditis in rocky mountain spotted fever. Arch Pathol Lab Med 104: 171-174. [Crossref]

47. Marin-Garcia J, Gooch WM, Coury DL (1981) Cardiac manifestations of rocky mountain spotted fever. Pediatrics 67: 358-361. [Crossref]

48. Helmick CG, Bernard KW, D'Angelo LJ (1984) Rocky mountain spotted fever: clinical, laboratory, and epidemiological features of 262 cases. J Infect Dis 150: 480488. [Crossref]

49. Paddock CD, Greer PW, Ferebee TL, Singleton Jr J, McKechnie DB, et al. (1999) Hidden mortality attributable to Rocky Mountain spotted fever: immunohistochemical detection of fatal, serologically unconfirmed disease. J Infect Dis 179: 1469-1476. [Crossref]

50. Maurin M, Raoult DF (1999) Q fever. Clin Microbiol Rev 12: 518-553. [Crossref]

51. Fournier PE, Etienne J, Harle JR, Habib G, Raoult D (2001) Myocarditis, a rare but severe manifestation of Q fever: report of 8 cases and review of the literature. Clin Infect Dis 32: 1440-1447. [Crossref]

52. Sheridan P, MacCaig JN, Hart RJ (1974) Myocarditis complicating Q fever. Br Med J 2: 155-156. [Crossref]

53. Maisch B (1986) Rickettsial perimyocarditis: a follow-up study. Heart and vessels 2: 55-59. [Crossref]

54. Levine HD (1946) Pathology study of thirty-one cases of scrub typhus fever with especial reference to the Cardiovascular System. Am Heart J 31: 314-328. [Crossref]

55. Yotsukura M, Aoki N, Fukuzumi N, Ishikawa K (1991) Review of a case of tsutsugamushi disease showing myocarditis and confirmation of Rickettsia by endomyocardial biopsy. Jpn Circ 55: 149-153. [Crossref]

56. Ognibene AJ, O'leary DS, Czarnecki SW, Flannery EP, Grove RB (1971) Myocarditis and disseminated intravascular coagulation in scrub typhus. Am J Med Sci 262: 233239. [Crossref]

57. Seong SY, Choi MS, Kim IS (2001) Orientia tsutsugamushi infection: overview and immune responses. Microbes Infect 3: 11-21. [Crossref]

58. Krause PJ, Bockenstedt LK (2013) Lyme disease and the heart. Circulation 127: e451454. [Crossref]

59. Konopka M, Kuch M, Braksator W, Walczak E, Jakuciński M, et al.(2013) Unclassified cardiomyopathy or Lyme carditis? A three-year follow-up. Kardiol Pol. 71: 283-285. [Crossref]

60. Ciuchi-Nicolau IE (2010) Acute myocarditis due to Leptospira Icterohaemorrhagiae-A case report. Ther Pharmacol Clin Toxicol 14: 140-145.

61. Forbes AE, Zochowski WJ, Dubrey SW, Sivaprakasam V (2012) Leptospirosis and Weil's disease in the UK. QJM: Int J Med 105: 1151-1162. [Crossref]
62. Wormser GP, Dattwyler RJ, Shapiro ED, Halperin JJ, Steere AC, et al. (2006) The clinical assessment, treatment, and prevention of Lyme disease, human granulocytic anaplasmosis, and babesiosis: clinical practice guidelines by the Infectious Diseases Society of America. Clin Infect Dis 43: 1089-1134. [Crossref]

63. Steere AC, Batsford WP, Weinberg M, Alexander J, Berger HJ, et al. (1980) Lyme carditis: cardiac abnormalities of Lyme disease. Ann Intern Med 93: 8-16. [Crossref]

64. Haddad FA, Nadelman RB (2003) Lyme disease and the heart. Front Biosci 8: s769-s782. [Crossref]

65. Arean VM (1962) The pathologic anatomy and pathogenesis of fatal human leptospirosis (Weil's disease). Am J Pathol 40: 393-423. [Crossref]

66. McBride AJ, Athanazio DA, Reis MG, Ko AI (2005) Leptospirosis. Curr Opin Infect Dis 18: 376-386. [Crossref]

67. Stuart RD (1939) Weil's disease in Glasgow sewer workers. $\mathrm{Br}$ Med J 1: 324-326. [Crossref]

68. Boland M, Sayers G, Coleman T, Bergin C, Sheehan N, et al. (2004) A cluste of leptospirosis cases in canoeists following a competition on the River Liffey. Epidemiology \& Infection 132: 195-200. [Crossref]

69. Nardone A, Capek I, Baranton G, Campèse C, Postic D, et al. (2004) Risk factors for leptospirosis in metropolitan France: results of a national case-control study, 19992000. Clin Infect Dis 39: 751-753. [Crossref]

70. Little JW (2005) Syphilis: an update. Oral Surg Oral Med Oral Pathol Oral Radiol Endod 100: 3-9. [Crossref]

71. Goh BT (2005) Syphilis in adults. Sex Transm Infect 81: 448-452. [Crossref]

72. Tennant R, Parks HW (1959) Myocardial abscesses. A study of pathogenesis with report of a case. Arch Pathol 68: 456-460. [Crossref]

73. Saphir O (1941) Myocarditis: a general review, with an analysis of two hundred and forty cases. Arch Pathol 32: 1000-1051.

74. Flaxman N (1943) Myocardial abscess. Jama 122: 804-806.

75. Sanson J, Slodki S, Gruhn JG (1963) Myocardial abscesses. Am Heart J 66: 301-318. [Crossref]

76. Abela GS, Majmudar B, Felner JM (1981) Myocardial abscesses unassociated with infective endocarditis. South Med J 74: 432-434. [Crossref]

77. Kim HS, Weilbaecher DG, Lie JT, Titus JL (1978) Myocardial abscesses. Am J Clin Pathol 70: 18-23. [Crossref]

78. Raev D (1997) Acute Staphylococcal myocarditis masquerading as an acute myocardial infarction. Int J Cardiol 60: 95-98. [Crossref]

79. Gladden JR, Peltier LF (1999) Myocardial abscess with perforation of the hear following Staphylococcal pyemia. Clin Orthop Relat Res 362: 6-11. [Crossref]

80. McCue MJ, Moore EE (1979) Myocarditis with microabscess formation caused by Listeria monocytogenes associated with myocardial infarct. Human Pathol 10: 469472. [Crossref]

81. Lewis JF (1973) Myocardial infarction during pregnancy: with associated myocardial Bacteroides abscess. South Med J 66: 379-381. [Crossref]

82. Maisch B, Alter P (2018) Treatment options in myocarditis and inflammatory cardiomyopathy. Herz 43: 423-430. [Crossref]

83. Bateman AC, Richards M, Pallett AP (1998) Fatal myocarditis associated with a Lancefield group B streptococcus. $J$ Infect 36: 354-355. [Crossref]

84. Cooper Jr LT (2009) Myocarditis. N Engl J Med 360: 1526-1538. [Crossref]

85. Smith SC, Ladenson JH, Mason JW, Jaffe AS (1997) Elevations of cardiac troponin I associated with myocarditis: experimental and clinical correlates. Circulation 95: 163168. [Crossref]

86. Lauer B, Niederau C, Kühl U, Schannwell M, Pauschinger M et al. (1997) Cardiac troponin $\mathrm{T}$ in patients with clinically suspected myocarditis. $J$ Am Coll Cardiol 30 1354-1359. [Crossref]

87. Mahfoud F, Gartner B, Kindermann M, Ukena C, Gadomski K et al. (2011) Virus serology in patients with suspected myocarditis: utility or futility? Eur Heart $J 32$ 897-903. [Crossref]

88. Morgera T, Di Lenarda A, Dreas L, Pinamonti B, Humar F et al. (1992) Electrocardiography of myocarditis revisited: clinical and prognostic significance of electrocardiographic changes. Am Heart J 124: 455-467. [Crossref] 
89. Nakashima H, Katayama T, Ishizaki M, Takeno M, Honda Y, et al. (1998) Q wave and non-Q wave myocarditis with special reference to clinical significance. Jpn Heart J 39: 763-774. [Crossref]

90. Magnani JW, Danik HJ, Dec Jr GW, DiSalvo TG (2006) Survival in biopsy-proven myocarditis: a long-term retrospective analysis of the histopathologic, clinical, and hemodynamic predictors. Am Heart J 151: 463-470. [Crossref]

91. Felker GM, Boehmer JP, Hruban RH, Hutchins GM, Kasper EK, et al. (2000) Echocardiographic findings in fulminant and acute myocarditis. $\mathrm{J} \mathrm{Am} \mathrm{Coll} \mathrm{Cardiol} \mathrm{36:}$ 227-232. [Crossref]

92. Gutberlet M, Spors B, Thoma T, Bertram H, Denecke T, et al. (2008) Suspected chronic myocarditis at cardiac MR: diagnostic accuracy and association with immunohistologically detected inflammation and viral persistence. Radiology 246: 401-409. [Crossref]

93. Friedrich MG, Strohm O, Schulz-Menger J, Marciniak H, Luft FC, et al. (1998) Contrast media-enhanced magnetic resonance imaging visualizes myocardial changes in the course of viral myocarditis. Circulation 97: 1802-1809. [Crossref]

94. Laissy JP, Messin B, Varenne O, Iung B, Karila-Cohen D, et al. (2002) MRI of acute myocarditis: a comprehensive approach based on various imaging sequences. Chest 122: 1638-1648. [Crossref]

95. Laissy JP, Hyafil F, Feldman LJ, Juliard JM, Schouman-Claeys E, et al. (2005) Differentiating acute myocardial infarction from myocarditis: diagnostic value of earlyand delayed-perfusion cardiac MR imaging. Radiolog 237: 75-82. [Crossref]

96. Laissy JP, Hyafil F, Feldman LJ, Juliard JM, Schouman-Claeys E, et al. (2005) Differentiating acute myocardial infarction from myocarditis: diagnostic value of earlyand delayed-perfusion cardiac MR imaging. Radiology 237: 75-82. [Crossref]

97. Abdel-Aty H, Boyé P, Zagrosek A, Wassmuth R, Kumar A, et al. (2005) Diagnostic performance of cardiovascular magnetic resonance in patients with suspected acute myocarditis: comparison of different approaches. J Am Coll Cardiol 45(11):1815-1822. [Crossref]

98. Yilmaz A, Mahrholdt H, Athanasiadis A, Vogelsberg H, Meinhardt G, et al. (2009). Coronary vasospasm as the underlying cause for chest pain in patients with PVB19 myocarditis. Heart 94: 1456-1463. [Crossref]

99. Friedrich MG, Sechtem U, Schulz-Menger J, Holmvang G, Alakija P, et al. (2009) Cardiovascular magnetic resonance in myocarditis: A JACC White Paper. $J$ Am Coll Cardiol 53: 1475-1487. [Crossref]

100. Mahrholdt H, Goedecke C, Wagner A, Meinhardt G, Athanasiadis A, et al. (2004) Cardiovascular magnetic resonance assessment of human myocarditis: a comparison to histology and molecular pathology. Circulation 109: 1250-1258. [Crossref]

101. Bozkurt B, Colvin M, Cook J, Cooper LT, Deswal A, et al. (2016) Current diagnostic and treatment strategies for specific dilated cardiomyopathies: a scientific statement from the American Heart Association. Circulation 134: e579-e646. [Crossref]

102. Godsel LM, Leon JS, Wang K, Fornek JL, Molteni A, et al. (2003) Captopril prevents experimental autoimmune myocarditis. J Immunol 171: 346-352. [Crossref]

103. Reyes MP, Khatib R, Khatib G, Ho KL, Smith F, et al. (1998) Prolonged captopril therapy in murine viral myocarditis. $J$ Cardiovasc Pharmacol Ther3: 43-49. [Crossref]

104. Bahk TJ, Daniels MD, Leon JS, Wang K, Engman DM (2008) Comparison of angiotensin converting enzyme inhibition and angiotensin II receptor blockade for the prevention of experimental autoimmune myocarditis. Int $J$ Cardiol 125: 85-93. [Crossref]

105. Seko Y (2006) Effect of the angiotensin II receptor blocker olmesartan on the development of murine acute myocarditis caused by coxsackievirus B3. Clin Sci 110 379-386. [Crossref]

106. Sukumaran V, Watanabe K, Veeraveedu PT, Thandavarayan RA, Gurusamy N, et al (2010) Beneficial effects of olmesartan, an angiotensin II receptor type 1 antagonist, in rats with dilated cardiomyopathy. Exp Biol Med 235: 1338-1346. [Crossref]

107. Veeraveedu PT, Watanabe K, Ma M, Palaniyandi SS, Yamaguchi KI, et al. (2008) Torasemide, a long-acting loop diuretic, reduces the progression of myocarditis to dilated cardiomyopathy. Eur J Pharmacol 581: 121-131.

108. Yuan Z, Shioji K, Kihara Y, Takenaka H, Onozawa Y, et al. (2004) Cardioprotective effects of carvedilol on acute autoimmune myocarditis: anti-inflammatory effects associated with antioxidant property. Am J Physiol Heart Circ Physiol 286: H83-H90. [Crossref]
109. Dickstein K, Cohen-Solal A, Filippatos G, McMurray JJ, Ponikowski P, et al. (2008) ESC Guidelines for the diagnosis and treatment of acute and chronic heart failure 2008: the task force for the diagnosis and treatment of acute and chronic heart failure 2008 of the European Society of cardiology. Eur J Heart Fail 10: 933-989. [Crossref]

110. Xiao J, Shimada M, Liu W, Hu D, Matsumori A (2009) Anti-inflammatory effects of eplerenone on viral myocarditis. Eur J Heart Fail 11: 349-353. [Crossref]

111. Pages ON, Aubert S, Combes A, Luyt CE, Pavie A, et al. (2009) Paracorporeal pulsatile biventricular assist device versus extracorporal membrane oxygenationextracorporal life support in adult fulminant myocarditis. $J$ Thorac Cardiovasc Surg 137: 194-197. [Crossref]

112. Duncan BW, Bohn DJ, Atz AM, French JW, Laussen PC, et al. (20010 Mechanical circulatory support for the treatment of children with acute fulminant myocarditis. The $J$ Thorac Cardiovasc Surg 122: 440-448. [Crossref]

113. Reinhartz O, Hill JD, Al-Khaldi A, Pelletier MP, Robbins RC, et al. (2005) Thoratec ventricular assist devices in pediatric patients: Update on clinical results. Asaio Journal 51: 501-503. [Crossref]

114. Topkara VK, Dang NC, Barili F, Martens TP, George I, et al. (2006) Ventricular assist device use for the treatment of acute viral myocarditis. Thorac Cardiovasc Surg 131: 1190-1191. [Crossref]

115. Cabinian AE, Kiel RJ, Smith F, Ho KL, Khatib R, et al. (1990) Modification of exercise-aggravated coxsackievirus B3 murine myocarditis by $\mathrm{T}$ lymphocyte suppression in an inbred model. J Lab Clin Med 115: 454-462. [Crossref]

116. Maron BJ, Ackerman MJ, Nishimura RA, Pyeritz RE, Towbin JA, et al. (20050 Task Force 4: HCM and other cardiomyopathies, mitral valve prolapse, myocarditis, and Marfan syndrome. J Am Coll Cardiol 45: 1340-1345. [Crossref]

117. Vogiatzis I, Dimoglou G, Sachpekidis V (2008) Q Fever myocarditis. Hippokrat 12 46-49. [Crossref]

118. Murcia J, Reus S, Climent V, Manso MI, López Í, et al. (2002) Acute myocardial failure in a young man: Q-fever myocarditis. Rev Esp Cardiol 2002 Aug 1;55(08):875877. [Crossref]

119. Hoefer D, Poelzl G, Kilo J, Hoermann C, Mueller L, et al. (2005) Early detection and successful therapy of fulminant Chlamydia pneumoniae myocarditis. ASAIO J 51: 480-481. [Crossref]

120. Walder G, Gritsch W, Wiedermann CJ, Pölzl G, Laufer G, et al. (2007) Co-infection with two Chlamydophila species in a case of fulminant myocarditis. Crit Care Med 35: 623-626. [Crossref]

121. Blauwet LA, Cooper LT (2010) Antimicrobial agents for myocarditis: target the pathway, not the pathogen. Heart 96: 494-495. [Crossref]

122. Ross SD (2001) Drug-related adverse events: a readers' guide to assessing literature reviews and meta-analyses. Arch Intern Med 161: 1041-1046. [Crossref]

123. Khan KS, Ter Riet G, Glanville J, Sowden AJ, Kleijnen J (2001) Undertaking systematic reviews of research on effectiveness: CRD's guidance for carrying out or commissioning reviews. NHS Centre for Reviews and Dissemination.

124. Bateson M (2004) Systematic Reviews to support evidence-based medicine: how to review and apply findings of healthcare research. postgrad med $j$ 80: 123.

125. Lee MG, Char G, Dianzumba S, Prussia P (1986) Cardiac involvement in severe leptospirosis. West Indian Med J 35: 295-300. [Crossref]

126. Garcia NS, Castelo JS, Ramos V, Rezende GS, Pereira FE (1999) Frequency of myocarditis in cases of fatal meningococcal infection in children: observations on 31 cases studied at autopsy. Rev Soc Bras Med Trop 32: 517-522. [Crossref]

127. Dung NM, Kneen R, Kiem N, Bethell DB, Phu NH, et al. (2002) Treatment of severe diphtheritic myocarditis by temporary insertion of a cardiac pacemaker. Clin Infect Dis 35: 1425-1429. [Crossref]

128. Trivedi SV, Bhattacharya A, Amichandwala K, Jakkamsetti V (2003) Evaluation of cardiovascular status in severe leptospirosis. J Assoc Physicians India 51: 951-954. [Crossref]

129. Kneen R, Dung NM, Solomon T, Giao PN, Parry CM, et al. (2004) Clinical features and predictors of diphtheritic cardiomyopathy in Vietnamese children. Clin Infect Dis 39: 1591-1598. [Crossref]

130. Salkade HP, Divate S, Deshpande JR, Kawishwar V, Chaturvedi R, et al. (2005) A study of autopsy findings in 62 cases of leptospirosis in a metropolitan city in India. J Postgrad Med 51: 169-173. [Crossref] 
131. Kole A, Roy R, Kar S (2012) Cardiac involvement in diphtheria: Study from a tertiary referral infectious disease hospital. Ann Trop Med Public Health 5(4):302-

132. Costello JM, Alexander ME, Greco KM, Perez-Atayde AR, Laussen PC (2009) Lyme carditis in children: presentation, predictive factors, and clinical course. Pediatrics 123: e835-841. [Crossref]

133. Gunasekaran K, Pichamuthu K, Sudarsan T, David T, Varghese G, et al. (2016) spectrum of cardiac manifestations and its relationship to outcomes in patients admitted with scrub typhus infection: A prospective observational cohort study from south India. Open Forum Infect Dis 3: 616

134. Chin JY, Kang KW, Moon KM, Kim J, Choi YJ (2018) Predictors of acute myocarditis in complicated scrub typhus: an endemic province in the Republic of Korea. Korean $J$ Intern Med 33: 323-330. [Crossref]

135. Karthik G, Sudarsan TI, Peter JV, Sudarsanam T, Varghese GM, et al. (2018) Spectrum of cardiac manifestations and its relationship to outcomes in patients admitted with scrub typhus infection. World J Crit Care Med 7: 16-23. [Crossref]

136. Melenotte C, Protopopescu C, Million M, Edouard S, Carrieri MP, et al. (2018) Clinical features and complications of Coxiella burnetii infections from the French National Reference Center for Q fever. JAMA Netw Open 1: e181580. [Crossref]

137. Samdani S, Jain A, Meena V, Meena CB (2018) Cardiac complications in diphtheria and predictors of outcomes. Int J Pediatr Otorhinolaryngol 104: 76-78. [Crossref]

138. McCully RB, Cooper LT, Schreiter S (2005) Coronary artery spasm in lymphocytic myocarditis: a rare cause of acute myocardial infarction. Heart 91: 202. [Crossref]

139. Hufnagel G, Pankuweit S, Richter A, Schönian U, Maisch B, et al. (2000). The European Study of Epidemiology and Treatment of Cardiac Inflammatory Diseases (ESETCID) First Epidemiological Results. Herz 25: 279-285. [Crossref]

140. Freedman SB, Haladyn JK, Floh A, Kirsh JA, Taylor G, et al. (2007) Pediatric myocarditis: emergency department clinical findings and diagnostic evaluation. Pediatrics 120: 1278-1285. [Crossref]

141. Amabile N, Fraisse A, Bouvenot J, Chetaille P, Ovaert C (2006) Outcome of acute fulminant myocarditis in children. Heart 92: 1269-1273. [Crossref]
142. Vignola PA, Aonuma K, Swaye PS, Rozanski JJ, Blankstein RL, et al. (1984) Lymphocytic myocarditis presenting as unexplained ventricular arrhythmias: diagnosis with endomyocardial biopsy and response to immunosuppression. $J \mathrm{Am}$ Coll Cardiol 4: 812-819. [Crossref]

143. Dec GW, Waldman H, Southern J, Fallon JT, Hutter AM, et al. (1992) Viral myocarditis mimicking acute myocardial infarction. $J$ Am Coll Cardiol 20: 85-89. [Crossref]

144. Kuhl U, Pauschinger M, Seeberg B, Lassner D, Noutsias M, et al (2005). Viral persistence in the myocardium is associated with progressive cardiac dysfunction. Circulation. 112: 1965-1970.

145. Nakashima H, Katayama T, Ishizaki M, Takeno M, Honda Y, et al. (1998) Q wave and non-Q wave myocarditis with special reference to clinical significance. Jpn Heart J 39: 763-774. [Crossref]

146. Greenwood RD, Nadas AS, Fyler DC (1976) The clinical course of primary myocardial disease in infants and children. Am Heart $J$ 92: 549-560. [Crossref]

147. Pinamonti B, Alberti E, Cigalotto A, Dreas L, Salvi A, et al. (1988) Echocardiographic findings in myocarditis. Am J Cardiol 62: 285-291. [Crossref]

148. Nieminen MS, Heikkilä J, Karjalainen J (1984) Echocardiography in acute infectious myocarditis: relation to clinical and electrocardiographic findings. Am J Cardiol 53: 1331-1337. [Crossref]

149. Mendes LA, Dec GW, Picard MH, Palacios IF, Newell J, et al. (1994) Right ventricular dysfunction: an independent predictor of adverse outcome in patients with myocarditis. Am Heart J 128: 301-307. [Crossref]

150. Angelini A, Calzolari V, Calabrese F, Boffa GM, Maddalena F, et al. (2000) Myocarditis mimicking acute myocardial infarction: role of endomyocardial biopsy in the differential diagnosis. Heart 84: 245-250. [Crossref]

151. Brito TD, Morais CF, Yasuda PH, Lancellotti CP, Hoshino-Shimizu S, et al. (1987) Cardiovascular involvement in human and experimental leptospirosis: pathologic findings and immunohistochemical detection of leptospiral antigen. Ann Trop Med Parasitol 81: 207-214. [Crossref]

Copyright: (C2019 Albakri A. This is an open-access article distributed under the terms of the Creative Commons Attribution License, which permits unrestricted use, distribution, and reproduction in any medium, provided the original author and source are credited. 